\title{
Representações e Respostas: Táticas no Combate ao Imaginário Racialista no Brasil e nos Estados Unidos na Virada do Século XIX
}

\author{
Sabrina Gledhill
}

\begin{abstract}
Resumo
Este artigo visa mostrar como Manuel R. Querino e Booker T. Washington usaram por meios diferentes a iconografia do negro para enfrentar os discursos sobre raça e identidade nacional construídos pelas ideologias fundamentadas no racialismo, que também produziram registros visuais, como as imagens somatológicas encomendadas no Brasil e nos Estados Unidos por Louis Agassiz.

Palavras-chave: Manuel R. Querino, Booker T. Washington, iconografia
\end{abstract}

\begin{abstract}
This article aims to show how, each in their own way, Manuel R. Querino and Booker T. Washington used images of black people to confront the discourses on race and national identity constructed by ideologies based on racialism, which also produced visual records such as the somatological pictures commissioned in Brazil and the United States by Louis Agassiz.
\end{abstract}

Key-words: Manuel R. Querino, Booker T. Washington, imagery

\section{Apresentação}

Reagindo a tentativas de utilizar a imagem do negro, representado em fotografias antropométricas ou somatológicas, para justificar a ideologia cientificista da suposta superioridade do branco, afrodescendentes nos Estados Unidos e no Brasil se insurgiram com outro tipo de imagem: do negro vestindo terno e gravata ou fardado, sozinho ou em família, sofisticado, culto, inteligente, participando de atividades educativas, cívicas e até nacionalistas para demonstrar seu patriotismo. Em alguns casos, como os do educador, autor e líder negro norte-americano Booker T. Washington (1856?-1915) e do educador, pesquisador, escritor e militante negro brasileiro Manuel R. Querino (1851-1923), negros eminentes produziam e divulgavam retratos deles mesmos, bem-vestidos, com poses e olhares que refletiam um ar de segurança e autoridade (ver Figs. 1 e 2). Segundo Turazzi, “Na Exposição Universal de Paris de 1878 [...] Aymar-Bression elogiava o fotógrafo que sabia produzir a pose mais vantajosa de seus modelos, um 'verdadeiro talento', em sua opinião"’. Algumas destas imagens são

\footnotetext{
${ }^{1}$ Doutoranda em Estudos Étnicos e Africanos, Centro de Estudos Afro-Orientais da Universidade Federal da Bahia (CEAO/UFBA). E-mail: sabrina.gledhill@gmail.com Orientador: Prof. Dr. Jeferson Bacelar. Agradeço as contribuições adicionais de Prof. Dr. Cláudio Pereira, Prof. Dr. Marcelo Cunha e Prof. Dr. João José Reis.

2 TURAZZI, Maria Inez. Poses e trejeitos, a fotografia e as exposiçôes na era do espetáculo (1839-1889). Rio de Janeiro: Funarte/Rocco, 1995, p. 14. A autora também observa que a maneira de se vestir do "modelo" e os objetos que o acompanhavam na foto, "eram capazes de definir, ou pelo menos produzir momentaneamente, a ilusão de um espírito aventureiro, uma vocação intelectual ou filosófica, glórias e poder” (Ibidem).
} 
assinadas, seguindo o estilo em voga, mas sem dúvida para enfatizar que também eram letrados numa época em que poucos negros eram sequer alfabetizados. ${ }^{3}$
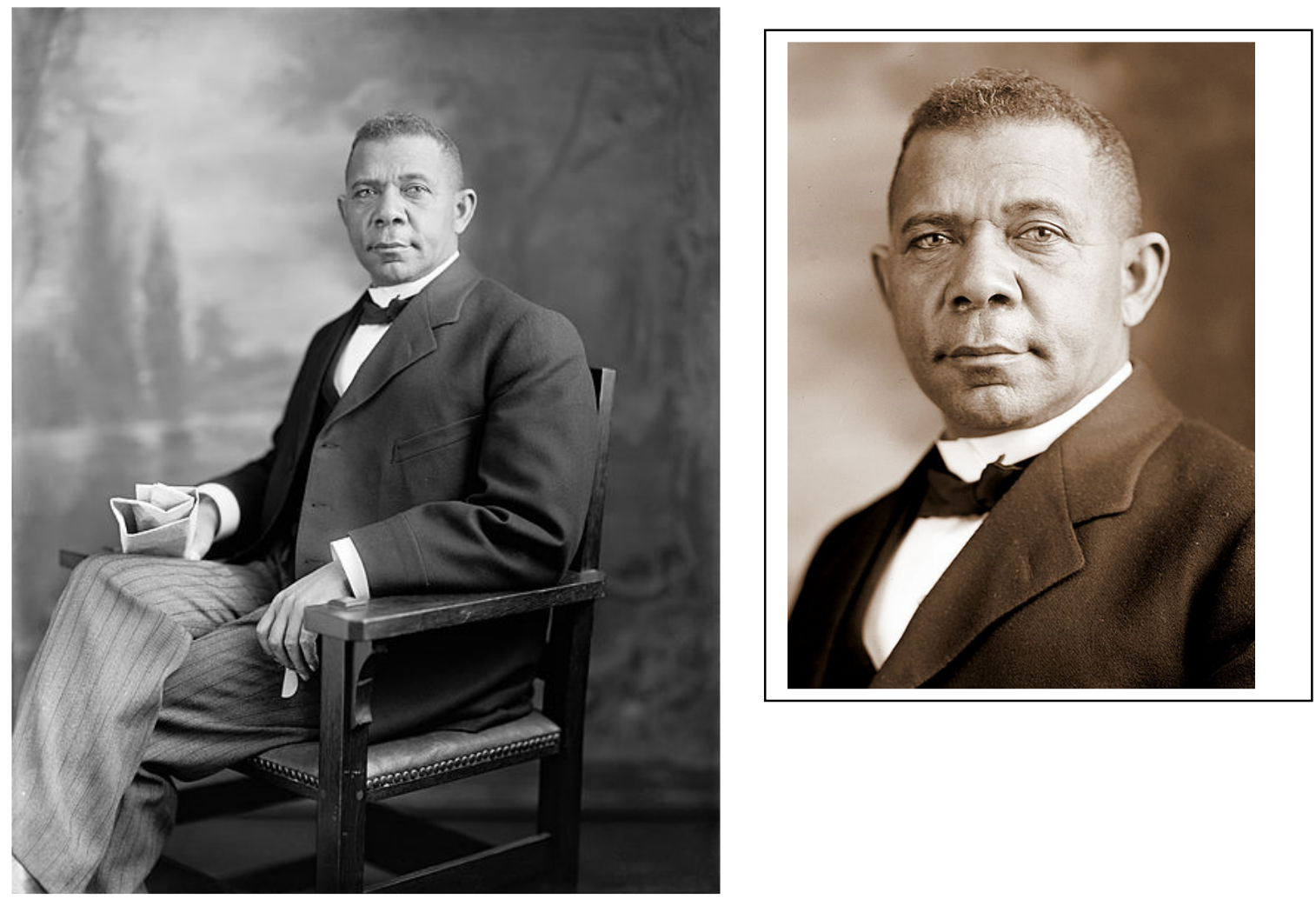

Figs 1 e 2 - Booker T. Washington em 1901 (Retrato e detalhe). Fonte: Wikipedia

As poucas fotografias que temos de Manuel Querino (em torno de 4) sempre mostram-no com uma expressão grave e uma pose séria ou até altiva (ver Figs. 3 e 4). Diferente de alguns afrodescendentes famosos, como Machado de Assis, Querino nada fez para "branquear" sua imagem. Pelo contrário, fez questão de mostrar que ele e muitos ilustres brasileiros eram "homens de cor preta". Por exemplo, as pranchas que ilustram a segunda edição de Artistas Babianos (1911) incluem apenas dois retratos - uma gravura do autor (baseada na fotografia que aparece na Fig. 3) e um desenho retratando o poeta, historiador e militar Ladislau da Silva Titára (1801-1861), autor da letra do Hino 2 de Julho quando alferes do Corpo de Estado-Maior do Exército e veterano da Independência. Titára aparece fardado,

\footnotetext{
${ }^{3}$ Nos Estados Unidos, os líderes afro-americanos Frederick Douglass e W.E.B. Du Bois também são exemplos desta prática.

${ }^{4}$ QUERINO, Manuel. "Os homens de côr preta na Historia." Revista do Instituto Geográfico e Histórico da Bahia, Salvador, 48, 353-363, 1923.
} 
ostentando quatro medalhas no peito, encimando a medalhão da Ordem da Rosa. ${ }^{5}$ Também fica evidente sua ascendência africana (ver Fig. 5).
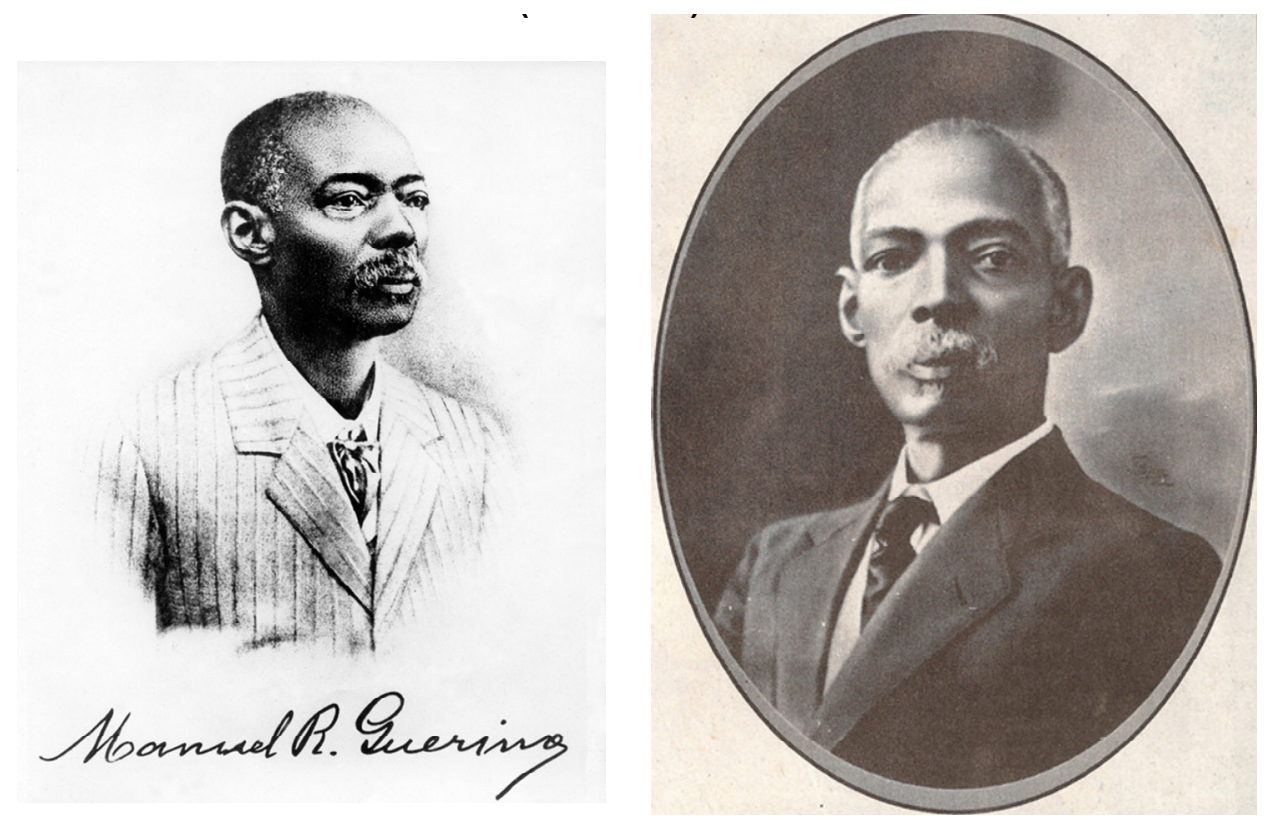

Figs 3 e 4 - Fotografias de Manuel R. Querino

5 Ladislau da Silva Titára foi cavaleiro da Ordem do Cruzeiro e oficial da Ordem da Rosa. No livro Artistas Babianos, Querino dedica apenas uma nota de rodapé ao poeta, portanto fica ainda mais intrigante a escolha de justamente esse retrato para ilustrar o livro (QUERINO, Manuel. Artistas Bahianos (indicações biographicas). 2a edição melhorada e cuidadosamente revista. Salvador: Officinas da Empreza "A BAHIA", 1911, p. 166, Nota 1). 


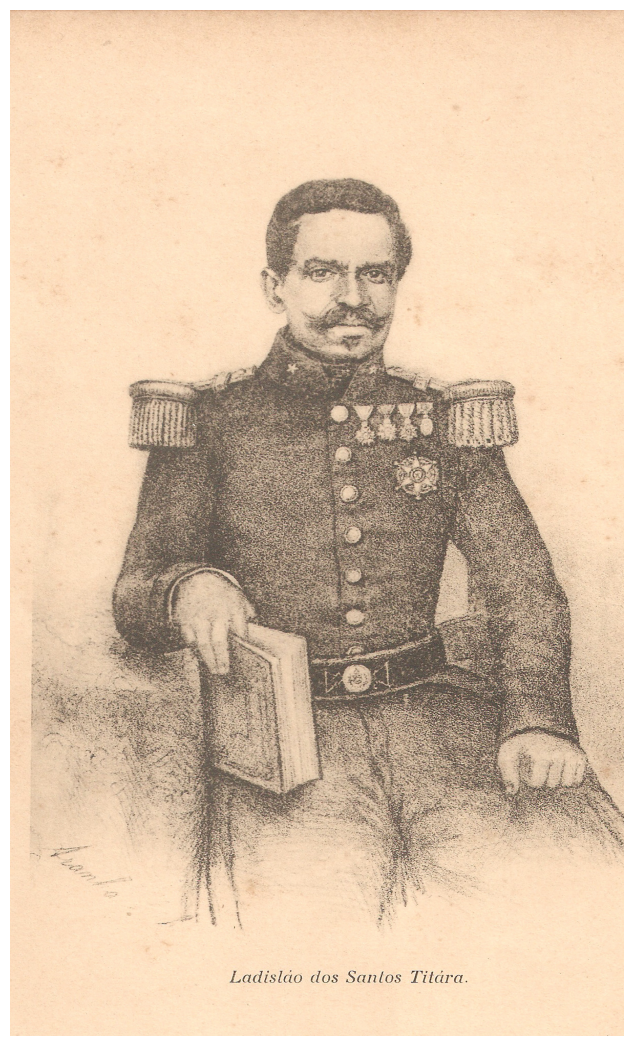

Fig 5 - Ladislau dos Santos Titára

Outro afro-brasileiro que utilizava esta tática foi Francisco Dias Coelho, o “coronel negro de Chapada Diamantina”. Segundo Moiseis de Oliveira Sampaio:

Nas fotografias, as imagens apresentadas eram diferenciadas a depender da camada social à qual eram dirigidas. Para os mais pobres, eram distribuídas fotografias envergando a farda da Guarda Nacional, assentado na cadeira que se assemelhava a um trono, com o semblante tranqüilo e imponente.[...] Para a elite, a fotografia era outra. Ele aparece com um terno, aparentemente bem ajustado com uma gravata alinhada, também demonstrando tranqüilidade com um semblante mais grave e solene, mas, em nada lembra a fotografia da farda, exceto o personagem fotografado. Para o destinatário desta foto, a imagem transmitia que o personagem retratado era um dos seus, também culto e rico, embora a fotografia não negasse a sua $\operatorname{cor}^{6}$.

Nisto, o Coronel Dias Coelho pode também ser comparado com Booker T. Washington, quem sempre dirigia as incontáveis imagens de sua pessoa (retratos de ateliê, imagens foto-jornalísticas, gravuras etc.) para o consumo de dois públicos - os brancos e os negros. Ele conhecia muito bem o gosto vitoriano dos filantropos brancos com os quais lidava

${ }^{6}$ SAMPAIO, Moiseis de Oliveira. O coronel negro: Coronelismo e poder no norte da Chapada Diamantina. Dissertação (Mestrado em História Regional e Local), UNEB, Salvador, 2009, p. 78. 
e, para eles, procurava projetar uma imagem de um intelectual de sensibilidade e bom gosto; para o público negro, projetava um ar de poder e autoridade. ${ }^{7}$

Os retratos de Washington, Querino e outros podem ser comparados com as fotografias que Mathew Brady tirou de ex-presidentes, militares e intelectuais norteamericanos, ${ }^{8}$ imagens de homens brancos e portanto "implicitamente racializadas" num período de "tensões raciais exacerbadas, a continuação do debate sobre a suposta questão do negro, segregação Jim Crow, a negação da cidadania do africano americano e o aumento dos linchamentos". Enfrentavam o dilema expresso por W.E.B. Du Bois nesta famosa observação:

\begin{abstract}
É um sentimento particular, esta dupla consciência, esta sensação de sempre olhar para o seu eu através dos olhos dos outros, de medir a sua alma com a régua de um mundo que o observa com divertido desprezo e piedade. Sua dualidade é constantemente sentida - um americano, um negro; duas almas, dois pensamentos, dois esforços inconciliáveis; dois ideais em guerra em um só corpo escuro, cuja força tenaz apenas é o que o impede de se dilacerar ${ }^{10}$.
\end{abstract}

Em graus diferentes, os retratos de negros livres e escravizados que enfatizavam sua "condição de pessoa" contradiziam os registros visuais que acompanharam os discursos sobre raça e identidade nacional construídos pelas ideologias fundamentadas no "racismo científico" ou cientificismo.

\title{
"Ser visto" v. "Dar-se a ver"
}

Referindo-se ao uso que se faz das imagens do fotografado, Roland Barthes reclama que: "os outros - o Outro - desapropriam-me de mim mesmo, fazem de mim, com ferocidade, um objeto, mantêm-me à mercê, à disposição, arrumado em um fichário, preparado para todas as trucagens sutis[....]"11. O crítico literário, semiólogo e filósofo francês não poderia ter colocado melhor a posição do negro escravizado, submetido a fotografias

\footnotetext{
7 BIEZE, Michael. Booker T. Washington and the Art of Self-Representation. Nova York: Peter Lang, 2008, p. 51-52. Sendo "o negro mais famoso do mundo" de sua época (BIEZE, 2008, p. 6), também havia imagens que Washington não podia controlar, como as caricaturas e charges publicadas nos jornais e nas revistas.

8 Ver TRACHTENBERG, Alan. Reading American Photographs: Images as History, Mathew Brady to Walker Evans. Nova York: Hill and Wang, 1990, p. 45 et. seq.

9 SMITH, Shawn Michelle. "Photographing the 'American Negro': Nation, Race and Photography at the Paris Exposition of 1900", In BLOOM, Lisa (ed.), With Other Eyes: Looking at Race and Gender in Visual Culture. Minneapolis e Londres: University of Minnesota Press, 1999, p. 58-87. P. 64-65.

${ }^{10}$ DU BOIS, W.E.B. The Souls of Black Folk. Nova York: Barnes \& Noble, 2003, p. 9, grifo nosso. W.E.B. Du Bois (1868/1963) foi sociólogo, historiador, pan-africanista, editor, autor, militante afro-americano e sóciofundador da Associação Nacional para o Progresso das Pessoas de Cor - NAACP.

${ }^{11}$ BARTHES, Roland. A câmara clara. Rio de Janeiro: Nova Fronteira, 1984, p. 29.
} 
antropométricas, somatológicas ou até simples registros do "exótico". Num ensaio sobre as fotografias de escravos brasileiros tiradas no século XIX por Christiano Jr., Manuela Carneiro da Cunha faz a seguinte observação:

\begin{abstract}
Num retrato, pode-se ser visto e pode-se dar a ver, alternativas que estão francamente ligadas à relação do retratado com o retratante. Quem encomenda uma fotografia mostra-se, dá-se a conhecer, esparrama-se pelo papel, a si e a seus atributos e propriedades, como gostaria de ser visto, como se vê a si mesmo no espelho. É o sujeito do retrato. [...] o escravo é visto, não se dá a ver. É visto sob formas que o despersonalizam de duas maneiras, mostrando-o seja como um tipo, seja como uma função ${ }^{12}$.
\end{abstract}

Através de uma pesquisa bibliográfica e iconográfica, podemos determinar que esta realidade antecede à fotografia. Por exemplo, retratos a óleo, desenhos e gravuras de negros livres foram utilizados por abolicionistas britânicos no século XVIII para demonstrar sua capacidade de "europeização" e inclusão na sociedade inglesa, como nos casos de Ignatius Sancho - retratado em 1768 pelo renomado artista plástico inglês Thomas Gainsborough - e Olaudah Equiano, entre outros ${ }^{13}$. Mesmo que estejam sendo utilizados como "garotos propaganda" pelo movimento que reivindicava a extinção da escravidão, fica evidente nas expressões, poses e vestimentas elegantes dos retratados que realmente estão "dando-se a ver". Em nada lembram os olhares vazios e as expressões sofridas dos negros escravizados, que futuramente seriam fotografados para fins "científicos".

Quando a fotografia se popularizou na segunda metade século XIX, apareceram duas vertentes da representação do ser humano - retratos privados e fotografias de "tipos". A primeira representava pessoas e outra, personagens, representantes de uma classe subalterna ou marginalizada, que poderia incluir doentes mentais, marginais ou escravos.

O uso de cartes-de-visite, seguidos por cartes-cabinet, no século XIX popularizou o costume de encomendar retratos de indivíduos e famílias, inclusive para marcar ritos de passagem como nascimentos, formaturas e enterros. Estas imagens foram produzidas aos milhões em estúdios fotográficos no mundo inteiro ${ }^{14}$. Segundo o historiador da Arte Brian Wallis: "Em geral, o objetivo do retrato fotográfico do século XIX era afirmar ou sublinhar o direito do indivíduo branco de classe média à condição de pessoa ('personhood')" ${ }^{15}$. Cunha

\footnotetext{
12 CUNHA, Manuela Carneiro da. "Olhar Escravo, Ser Olhado", In AZEVEDO, Paulo Cesar de, e LISSOVSKY, Mauricio (Orgs.). Escravos brasileiros do século XIX na fotografia de Christiano Jr. São Paulo: Ex Libris, 1988, p. xxiii.

${ }^{13}$ KING, Reyahn et alii. Ignatius Sancho: An African Man of Letters. Londres: National Portrait Gallery, 1997.

${ }^{14}$ BECKER, William B. “Cabinet Cards", In HANNAVY, John (ed.), Encyclopedia of Nineteenth-Century Photography, vol. 1, p. 233-234. Nova York: Routledge, 2008. P. 233-234.

15 WALLIS, Brian. "Black Bodies, White Science: Louis Agassiz’s Slave Daguerreotypes”, In American Art, vol. 9, no. 2 (Summer 1995), p. 39-61. P. 55.
} 
observa que "a fotografia do senhor" era "singularizante", tornando-se "literalmente, como se dizia à época, um 'cartão de visita'. É uma imagem de si que se exige ao fotógrafo. A série que produz é um conjunto de idênticos para serem oferecidos a pares" ${ }^{\prime 16}$.

De outro lado, as imagens de escravos e negros libertos ou livres e fotografias de "tipos" são geralmente anônimas. Segundo Cunha:

Não é o rosto único do retratado que se busca no "tipo", mas a generalidade que permite reconhecê-lo como um "negro mina," "gabão", "cabinda", "crioulo". Enquanto tipo, ele está ali como sinal de uma categoria que o subsume, outra coisa que não ele, maior do que ele, e na qual sua especificidade (por mais que seu rosto, único, seja indelével no retrato) se torna irrelevante. Menor que o personagem, ao contrário, é a função. A vendedora de frutas, o carregador, o barbeiro tampouco são pessoas $[\ldots . . .]^{17}$.

Nas imagens de escravos tiradas no Brasil, todos estão descalços, como "sinal de escravidão" (ver Fig. 6) ${ }^{18}$. Alguns estão parcialmente vestidos ou despidos, desumanizados e retratados com a intenção de comprovar a suposta superioridade da "raça branca". Como Cunha observa:

\begin{abstract}
A fotografia do escravo, que não o individualiza, que o vê de fora, não lhe é destinada nem a seus pares: é vendida 'ao viajante ou a quem se retira para a Europa", fixa uma imagem do Brasil para uso no exterior. Por isso a série significativa é o conjunto das fotografias que evocam tipos humanos e ofícios. Se o retrato do senhor é uma forma de cartão de visita, o retrato do escravo é uma forma de cartão postal: um quer descrever a pessoa, digna e singular, outro descreve o personagem, pitoresco e genérico ${ }^{19}$.
\end{abstract}

\footnotetext{
${ }^{16}$ Cunha, "Olhar Escravo, Ser Olhado", 1988, p. xxiv.

${ }^{17}$ Cunha, 1988, p. xxiii.

${ }^{18}$ Cunha, 1988, p. xxiii.

${ }^{19}$ Cunha, 1988, p. xxiv.
} 


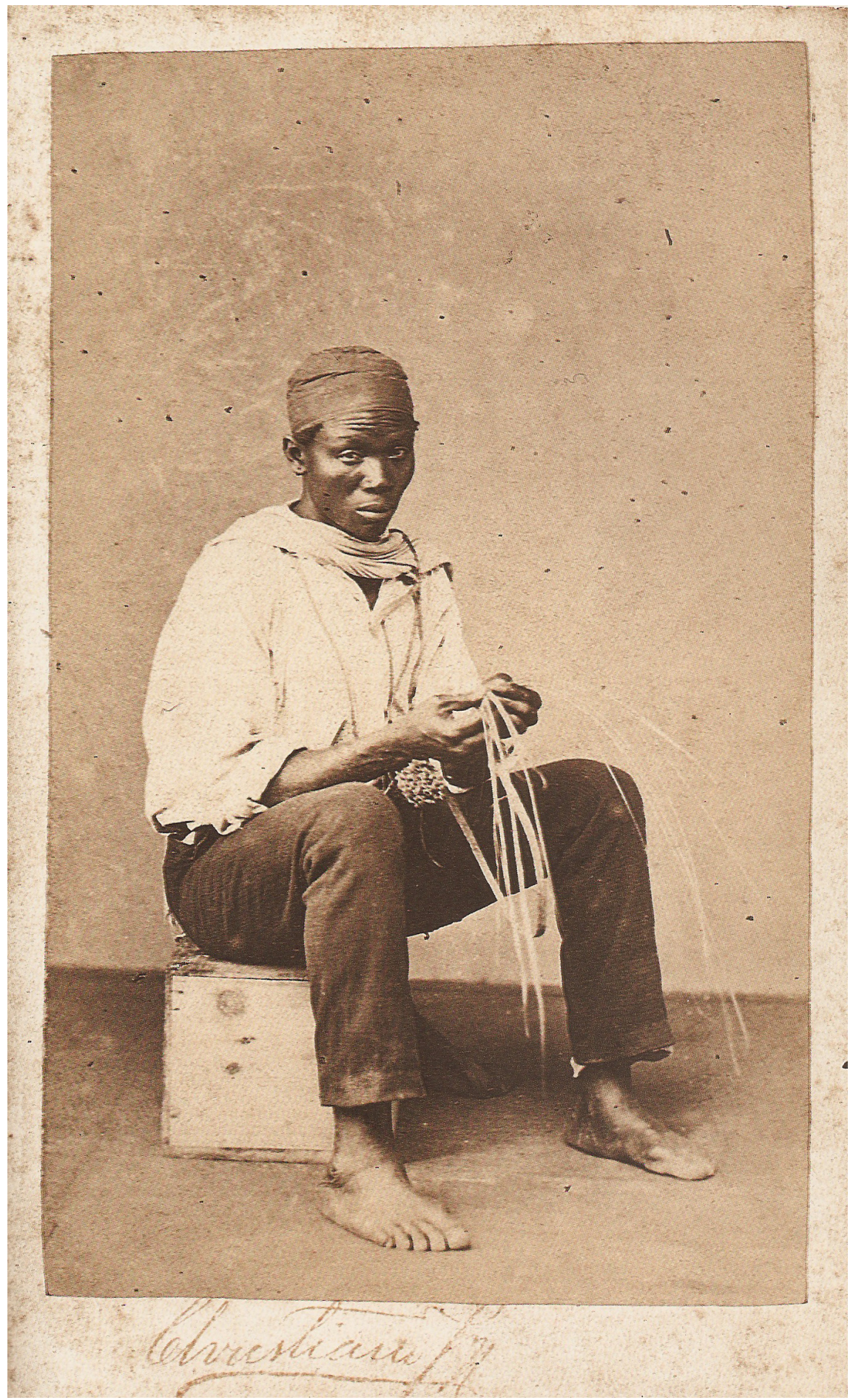

Fig 6 - Fotografia de um escravo anônimo da autoria de Christiano Jr.

Outra maneira de "ver de fora" e transformar o sujeito retratado em um objeto que "é visto", foi a fotografia antropométrica, uma metodologia idealizada pelo antropólogo 
inglês Francis Galton, o "pai da eugenia” e primo de Charles Darwin. No século XIX, estas fotografias eram usadas para "mapear" os corpos de "marginais" nas prisões, assim como nas análises científicas de gênero e raça. Galton criou duas metodologias para registrar supostos índices físicos de divergências biológicas fundamentais: retratos compostos e um sistema padronizado de fotografia familiar ${ }^{20}$. Tentou identificar uma relação entre as feições físicas dos retratados que pudesse levar a um diagnóstico de doenças e até tendências criminosas. No final da vida, depois de muitas experiências, teve que admitir a impossibilidade de obter estes “tipos” na prática.

Para os cientificistas norte-americanos, o conceito do "American Negro" seria uma contradição, uma vez que a nacionalidade estadunidense era vista como uma denominação exclusivamente branca e anglo-saxônica. Assim como o Conde de Gobineau e Nina Rodrigues afirmavam a inferioridade dos mestiços brasileiros, ${ }^{21}$ Galton acreditava que a miscigenação nos Estados Unidos resultaria numa descendência "tragicamente enfraquecida" e serviria para diluir e enfraquecer o "caráter nacional". A teoria da eugenia de Galton forneceu a base científica da hierarquia racializada do "Outro" dispostas nas exposições universais na virada do século XIX 22 .

Segundo Mirzoeff, "O corpo perfeito na cultura Ocidental foi sustentado e tornou-se imaginável através do corpo imperfeito do Outro racializado",23. Na sua análise de fotografias de negros tiradas no Congo Belga pelo zoólogo alemão Herbert Lang no início do século XX, o autor observa que, para gerações de racialistas,

\begin{abstract}
o impulso divino na direção da perfeição era tão marcado pela inferioridade do corpo Africano como pela perfeição do branco. Essa profunda diferença interna era necessária para marcar a superioridade do branco e convencer o européu que o Outro não fazia parte do Eu, que o colonizador era radicalmente diferente de - e superior a - o colonizado ${ }^{24}$.
\end{abstract}

A fotografia somatológica de escravos e libertos tidos como "tipos" e "representantes" de "tribos" africanas foi introduzida e aperfeiçoada nos Estados Unidos e no Brasil pelo zoólogo e geólogo naturalizado norte-americano Jean Louis Rodolphe Agassiz. Nascido na Suíça, Agassiz foi escolhido por Karl Friedrich Philipp von Martius para continuar

${ }^{20}$ SMITH, 1999, "Photographing the "American Negro", p. 62.

21 Ver RODRIGUES, Raimundo Nina. As raças humanas e a responsabilidade penal no Braz̧il. Bahia: Imprensa Popular, 1894, esp. cap. VI.

22 SMITH, 1999, p. 60.

${ }^{23}$ MIRZOEFF, Nicholas. Bodyscape: Art, modernity and the ideal figure. Londres e Nova York: Routledge, 1995, p. 135.

${ }^{24}$ MIRZOEFF, 1995, p. 136. 
as investigações Johann Baptist von Spix sobre os peixes brasileiros de água doce quando este faleceu em 1826. Agassiz também liderou a expedição Thayer para o Brasil entre 1865 e 1866, junto com sua esposa, a educadora norte-americana Elizabeth Cabot Cary Agassiz, e contratou os fotógrafos Georges Leuzinger e Augusto Stahl para ilustrar o livro que escreveu sobre suas pesquisas neste país, em colaboração com sua esposa. Entretanto, o projeto de Agassiz de fotografar "tipos" africanos teve origem cerca de quinze anos antes, nos Estados Unidos.

A idéia de representar "tipos humanos" não foi originalmente de Agassiz, mas ele foi um dos pioneiros nesta área quando mandou fotografar escravos numa plantation do estado da Carolina do Sul. Segundo Wallis ${ }^{25}$, a idéia pode ter surgido em 1846, quando Agassiz conheceu Samuel George Morton, um dos líderes da escola norte-americana de poligenia e colecionador de seis centenas de caveiras de índios norte-americanos ${ }^{26}$. $\mathrm{Na}$ ocasião, Morton presenteou o naturalista com um daguerreótipo de um jovem africano que tinha exposto na Academia de Ciências Naturais da Filadélfia ${ }^{27}$.

O que sabemos é que Agassiz iniciou o projeto durante visita a uma "plantation" nas vizinhanças da cidade de Columbia. A importação legal de africanos foi proibida nos Estados Unidos em 1808, mas segundo o colega que sugeriu esta visita, Dr. Robert W. Gibbes, Agassiz ficou muito animado quando encontrou "Negros Ebo, Foullah, Gullah, Guinea, Coromantee, Mandrigo e Congo" em números suficientes para "deixá-lo satisfeito que eram diferentes das outras raças" (Ibidem, p. 45). A pedido de Agassiz, Gibbes mandou vários dos sujeitos escravizados ao ateliê de Joseph T. Zealy para serem fotografados. Um dos resultados pode ser visto na Figura 7. Estas imagens foram exibidas na Exposição Internacional Colombiana de 1893, realizada na cidade de Chicago para comemorar a descoberta da América $^{28}$, evento no qual a participação oficial dos negros norte-americanos foi excluída. $^{29}$

\footnotetext{
${ }^{25}$ WALLIS, Brian. "Black Bodies, White Science: Louis Agassiz's Slave Daguerreotypes", In American Art, vol. 9, no. 2 (Summer 1995), p. 39-61. P. 45.

${ }^{26}$ GOULD, Stephen Jay. A falsa medida do homem. São Paulo: Martins Fontes, 2003, p. 40-41.

${ }^{27}$ WALLIS, 1995, p. 45.

28 TURAZZI, Poses e trejeitos, 1995, p. 241.

${ }_{29}$ Apenas reservaram um dia para os negros - "Colored People’s Day" no dia 25 de agosto de 1893 - quando o abolicionista e ex-escravo Frederick Douglass enfrentou humilhações para proferir o último discurso de sua vida (WESTERBECK, Colin L. “ Frederick Douglass Chooses His Moment”. Museum Studies. The Art Institute of Chicago, 2000. Disponível em <http://www.artic.edu/webspaces/museumstudies/ms242/westerbeck1.shtml> Acessado em 28 de Agosto 2009, p. 147).
} 


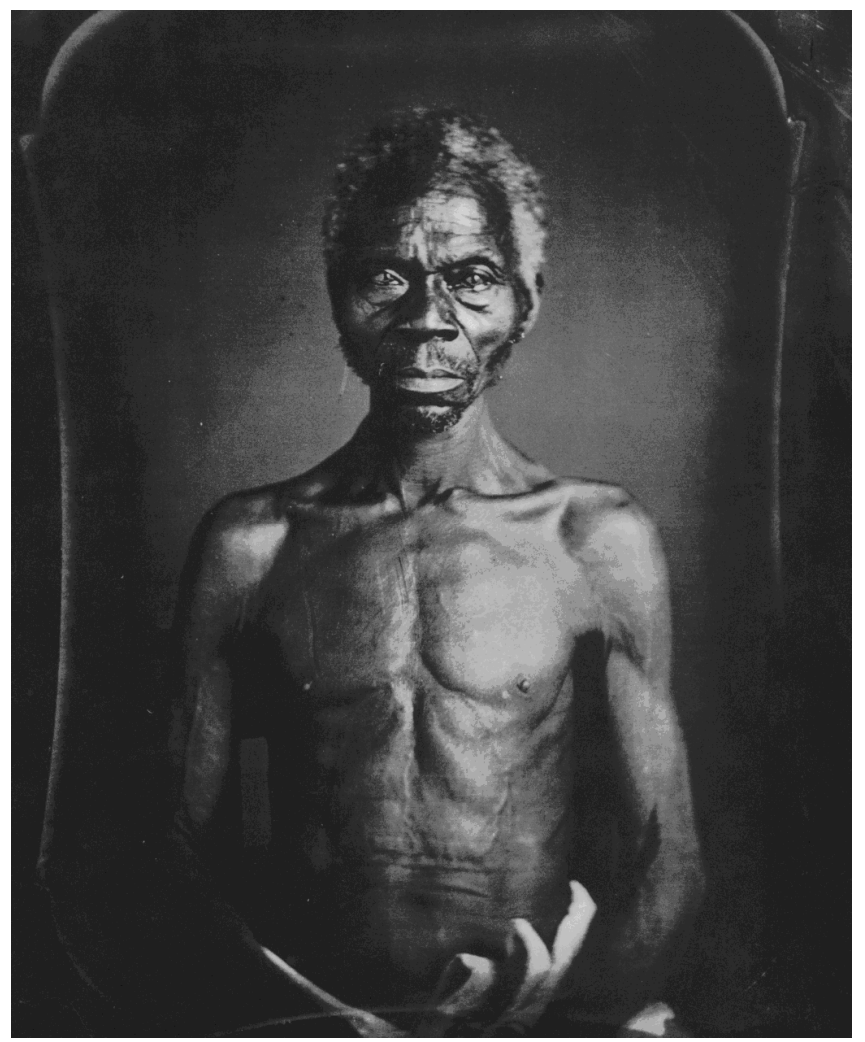

"Renty," Congo.

Plantation of B. F.

Taylor, Esq." Daguerreótipo

J. T. Zealy, Columbia, S.C., March

1850. Peabody Museum, Harvard

University

Fonte: WALLIS 1995, p. 39

Fig. 7

Segundo Trachtenberg, as imagens de escravos africanos produzidas por Zealy "Figuram entre os retratos daguerreótipos mais extraordinários feitos nos Estados Unidos" e refletem o "poder absoluto do senhor sobre o escravo". Também podem ter servido para "atiçar as paixões abolicionistas" 30 . Desde os primeiros tempos da técnica da daguerreotopia:

O olhar era primordial, e o que fazer com os olhos, o problema principal. Para evitar a expressão vazia ou triste e carrancuda do olhar direto, frontal, perante a câmera, o francês Lerebours aconselhava que os fotógrafos fizessem com que seus modelos olhassem 'vagamente para um objeto distante'[....] Os modelos eram incentivados e persuadidos a usar sua força de vontade para obter a expressão desejada - enfim, um papel e uma máscara que estivessem de acordo com sua auto-imagem ${ }^{31}$.

Despidos dessa máscara, "o olhar dos africanos escravizados só pode revelar as profundezas do seu ser, porque, sendo escravos nus, não são permitidos uma persona social”, ${ }^{32}$.

\footnotetext{
30 TRACHTENBERG, Alan. Reading American Photographs, 1990, p. 53-54.

31 TRACHTENBERG, 1990, p. 26.

32 TRACHTENBERG, 1990, p. 56.
} 
Brian Wallis observa que os daguerreótipos de escravos que Agassiz encomendou e exibiu na Exposição Colombiana:

[...] tiveram dois objetivos, um nominativamente científico e outro explicitamente político. Foram criados para analisar as diferenças físicas entre os brancos europeus e os negros africanos, mas ao mesmo tempo, tiveram a intenção de comprovar a superioridade da raça branca. Agassiz esperava utilizar estas imagens para comprovar sua teoria da 'criação separada' - a idéia que as várias raças da humanidade seriam, de fato, espécies distintas ${ }^{33}$.

O comentário de George Ermakoff sobre as fotografias tiradas pela Expedição Thayer no Brasil reforça esta observação:

[...] as fotografias antropométricas tinham o objetivo de apoiar estudos científicos comparativos sobre a raça humana. Acreditava-se, então, que a observação sobre eventuais diferenças físicas entre as diversas raças poderia comprovar cientificamente teorias sobre superioridade racial - hoje consideradas preconceituosas. Foi posteriormente comprovado que fotografias antropométricas feitas com esta intenção não tiveram nenhum valor científico relevante ${ }^{34}$.

Os produtos fotográficos da Expedição que hoje se encontram no Peabody Museum of Anthropology and Ethnology, da Universidade de Harvard, nos Estados Unidos também incluem fotografias antropométricas de africanos e afrodescendentes que refletem o racismo científico de Agassiz e retratam os sujeitos de uma maneira subumana e degradante. ${ }^{35}$ Agassiz utilizava a fotografia somatológica para reiterar uma hipótese - a suposta "inferioridade do negro" - que, para ele, já estava mais que comprovada. Quanto aos negros "vistos" nas fotos, nas palavras de um descendente de um "rei africano escravo": "a humilhação fica presente como cicatriz, sempre a abrir em ferida"36.

\footnotetext{
33 WALLIS, "Black Bodies, White Science", 1995, p. 40.

34 ERMAKOFF, George. O negro na fotografia brasileira do século XIX. Rio de Janeiro: George Ermakoff Casa Editorial, 2004, p. 251.

${ }^{35}$ Num trabalho recente, a historiadora brasileira Maria Helena Machado e a artista plástica suíça Sasha Huber se debruçaram sobre as fotografias encomendadas por Agassiz para analisar "tipos" raciais, inclusive "raças mistas" (MACHADO, Maria Helena, e HUBER, Sasha. (T)races of Louis Agassiz: Photography, Body and Science, Yesterday and Today/Rastros e Raças de Louis Agassiz: Fotografia, Corpo e Ciência, Ontem e Hoje. Publicado na ocasião da 29a Bienal de São Paulo. São Paulo: Capacete Entretenimentos, 2010). Huber aparece numa foto intitulada "Triptico somatológico de Sasha Huber. Furnas de Agassiz, Floresta da Tijuca, Rio de Janeiro, 2010" (MACHADO e HUBER 2010, p 124-125 e 135), a qual, produzida com a evidente intenção de protestar contra as imagens "científicas" que mostram o "objeto" despido, de costas, de lado e de frente na mesma foto, também serve para mostrar a diferença marcante entre esta foto-protesto e as imagens encomendadas por Agassiz. Nesta imagem, a artista plástica "se dá a ver".

${ }^{36}$ COUVE, Antenor Boaventura. Narrativa de um Descendente de um rei africano escravo na Bahia, publicada na revista Almanaque Do Mensageiro da Fé, Ano 1964. pág. 96/99 - Salvador/BA. Disponível em: <http://bahiatextos.blogspot.com/2010/05/meu-avo-rei-ossurumis.html> Acesso em: 13.01.11.
} 


\section{Exposições (quase) universais}

Como sabemos, muitas imagens de negros - vistos como sujeitos e objetos - foram exibidas nas exposições universais que se popularizaram no século XIX. Na grande maioria destes eventos, o negro aparecia apenas para "ser visto", ou em fotografias ou em "zoológicos humanos" ${ }^{37}$. Segundo Turazzi, nessas exposições, "A imagem do negro - quando presente havia estado de modo geral dissociada da escravidão e, em muitos casos, francamente impregnada por um europocêntrico interesse etnográfico pelas raças consideradas inferiores”38.

Depois da experiência humilhante da Exposição Internacional Colombiana de 1893, W.E.B. Du Bois e Booker T. Washington, entre outros, trataram de organizar a famosa exposição sobre o negro norte-americano conhecida como a Exposé Nègre ou "American Negro Exhibit” na Exposição Universal de Paris de 1900. W.E.B. Du Bois, que participou com álbuns de fotografias de negros de várias cores intitulados "A vida do negro na Geórgia", observou que esta exposição foi "planejada e realizada por negros e colecionada e instalada sob a direção de um comissário especial negro, o Sr. Thomas J. Calloway" 39 . Entre os vários álbuns expostos na Exposé Nère, a série de imagens produzidas por Frances Benjamin Johnston, uma fotógrafa branca norte-americana, retratando os estudantes do Instituto Hamilton (ver, por exemplo, Fig. 8), representa novas estratégias visuais que visavam a representação explicitamente racializada de um aspecto da nacionalidade norte-americana e confrontavam o determinismo biológico que reforçava o racismo científico de Galton. As fotografias de Johnston criaram outra imagem do "caráter norte-americano" 40 .

Segundo Smith, essas imagens dialogam com, e contradizem, outras fotografias num contexto histórico caracterizado pela sua fluidez e mutabilidade. Smith observa que: "a cultura virtual não é um mero reflexo de uma comunidade imaginada, mas um dos sítios onde as narrativas de inclusão são produzidas e propulsionadas" e sugere que, muito mais que uma simples referência para imagens fotográficas, a nação seria um produto dessas imagens. Essas fotografias teriam iniciado "uma nova estratégia visual para a representação de raça e caráter nacional na virada do século" ${ }^{41}$.

\footnotetext{
${ }^{37}$ BLANCHARD, Pascal et alii (eds.) Human Zoos : Science and Spectacle in the Age of Colonial Empires, traduzido por Teresa Bridgeman. Liverpool: Liverpool University Press, 2008.

38 TURAZZI, Poses e trejeitos, 1995, p. 151.

39 SMITH "Photographing the "American Negro", 1999, p. 59

40 SMITH, "Photographing the "American Negro", 1999, p. 59.

${ }^{41}$ SMITH, 1999, p. 59.
} 
Fig. 8

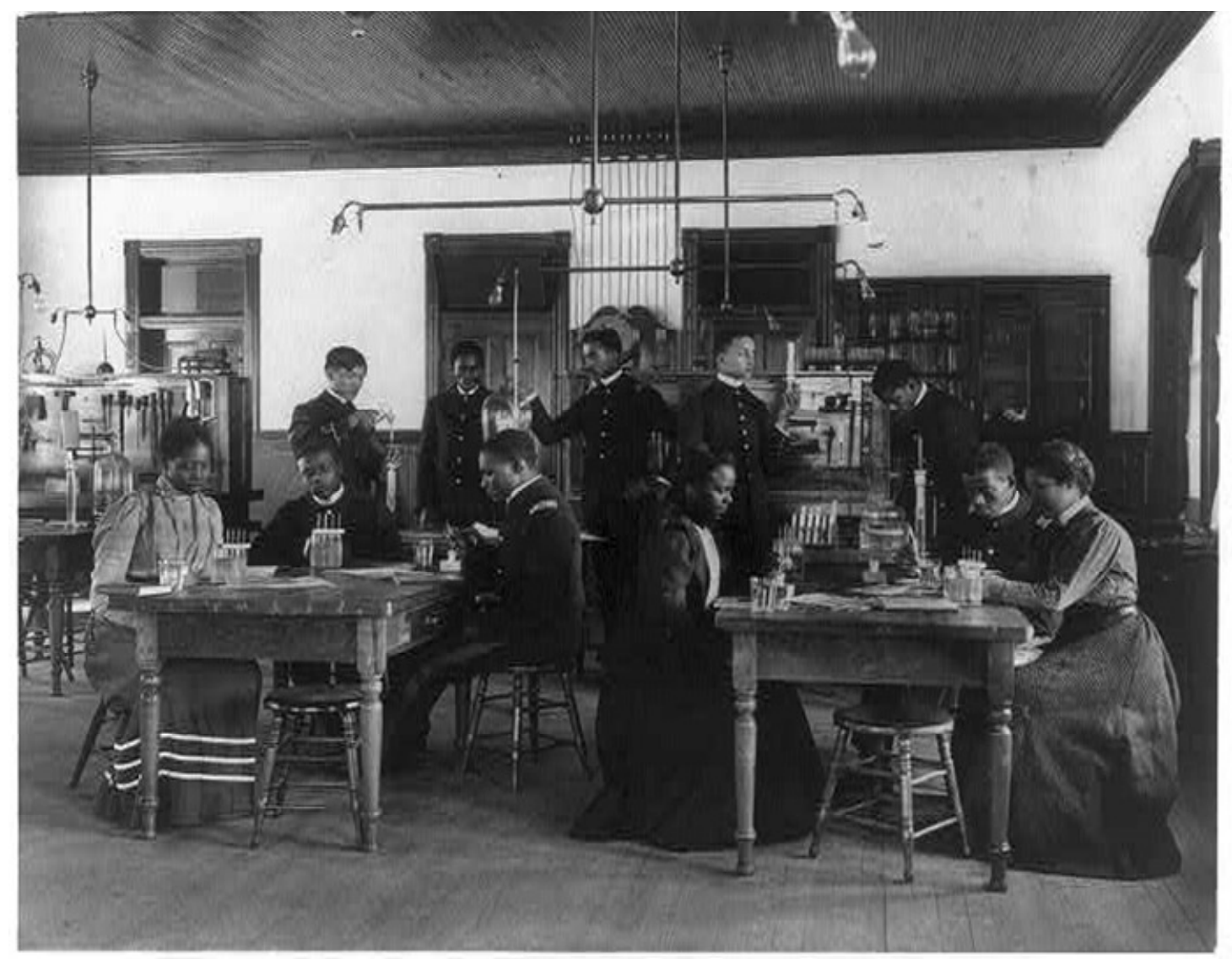

\section{Aula de Química}

Chemistry classroom at Hampton Institute - African American male and

female students, one Indian

$\mathrm{Na}$ análise de Smith, o interesse preeminente da Exposé Nègre seria estabelecer o lugar do "Negro" (em inglês) nos Estados Unidos através da análise dos códigos visuais utilizados na fotografia da virada do século XIX. A “American Negro Exhibit" em Paris marcou o início de uma "nova era na história da representação racial". Por representar os negros norte-americanos como integrantes plenos da civilização ocidental, esta exposição se diferenciava das representações do negro vistas em outros eventos antes e depois, que reproduziam aldeias africanas com figurantes nem sempre africanos e serviam para reforçar a idéia de superioridade que os europeus tinham em relação aos "selvagens negros". Além de fotografias, a exposição utilizou mapas, gráficos, maquetes, descrições minuciosas dos esforços feitos para instruir o negro norte-americano e centenas de obras literárias produzidas por 
autores negros para demonstrar os avanços realizados pelo negro, medidos pelos critérios da cultura ocidental e branca. Instalada no Palácio de Economia Social, a Exposé Nègre tanto impressionou o público e os jurados que ganhou um Grande Prêmio da Exposição Universal de Paris. De outro lado, segundo Smith, a exposição foi apresentada no contexto de "soluções aos problemas nacionais" dos Estados Unidos - neste caso, representava uma suposta solução ao "problema do negro". Portanto, ficava "confinada dentro do sistema de vigilância social dominado pelo branco" ${ }^{42}$.

Segundo algumas fontes, ${ }^{43}$ as fotos do Instituto Hampton apresentadas na exposição em Paris foram encomendadas por Booker T. Washington, mas segundo Smith, Johnston produziu as imagens a convite do segundo reitor desta instituição, Hollis Gurke Frissel ${ }^{44}$. De qualquer modo, Johnston também fotografou o Instituto Tuskegee, do qual Washington era fundador e reitor, em 1902. ${ }^{45}$ Esta série, que inclui retratos de Washington (Fig. 9), o Conselho Executivo e as instalações, representa os alunos desta instituição da mesma maneira que os do Instituto Hampton foram retratados para a exposição de 1900 - bem-vestidos, sérios e patrióticos, nunca olhando para a câmera, fazendo parte de outro mundo, distante do observador, mas refletindo valores europeus de civilização. ${ }^{46}$ Principalmente, essas fotografias contradizem qualquer imagem do negro como "preguiçoso", "selvagem”, “desinteligente” ou muito importante para Washington - "perigoso", principalmente para os brancos. O perigo para os negros, segundo Smith, residia no fato que estas imagens também poderiam sustentar a hipótese que o sistema da segregação de raças "separadas mas iguais" estava funcionando a contento nos Estados Unidos. ${ }^{47}$

\footnotetext{
42 SMITH, 1999 , p. 58 e 60.

43 MAXELL, Anne. "Montrer l'Autre: Franz Boas et les soeurs Gerhard", In BANCEL, Nicolas, et alii, Zoos bumains. De la Vénus hottentote aux reality shows. Paris: La Découverte, 2002. p. 331-339. Conhecendo a grande influência exercida por Booker T. Washington na sua alma mater, é muito provável que ele tenha sido a "eminência parda" por trás das fotografias produzidas para a Exposição de 1900.

44 SMITH, "Photographing the 'American Negro", 1999, p. 65.

45 Washington posou para, e contratou vários, fotógrafos, brancos e negros, homens e mulheres (BIEZE. Booker T. Washington and the Art of Self-Representation, 2008).

46 Smith sugere que os alunos do Instituto Hampton foram proibidos de olhar para a fotógrafa branca, uma vez que isto era um "delito" que poderia levar ao linchamento na época (1999, p. 66-67). Entretanto, as fotografias do Instituto Tuskegee encomendadas por Washington seguem a mesma linha, a qual, segundo Bieze, refletia a estética do movimento de Artes e Ofícios que se instalou como uma reação à revolução industrial, valorizando o trabalho e principalmente o trabalho artesanal (BIEZE, 2008, p. 92-93). Um exemplo seria os quadros do pintor Millet.

${ }^{47}$ SMITH 1999, p. 72.
} 


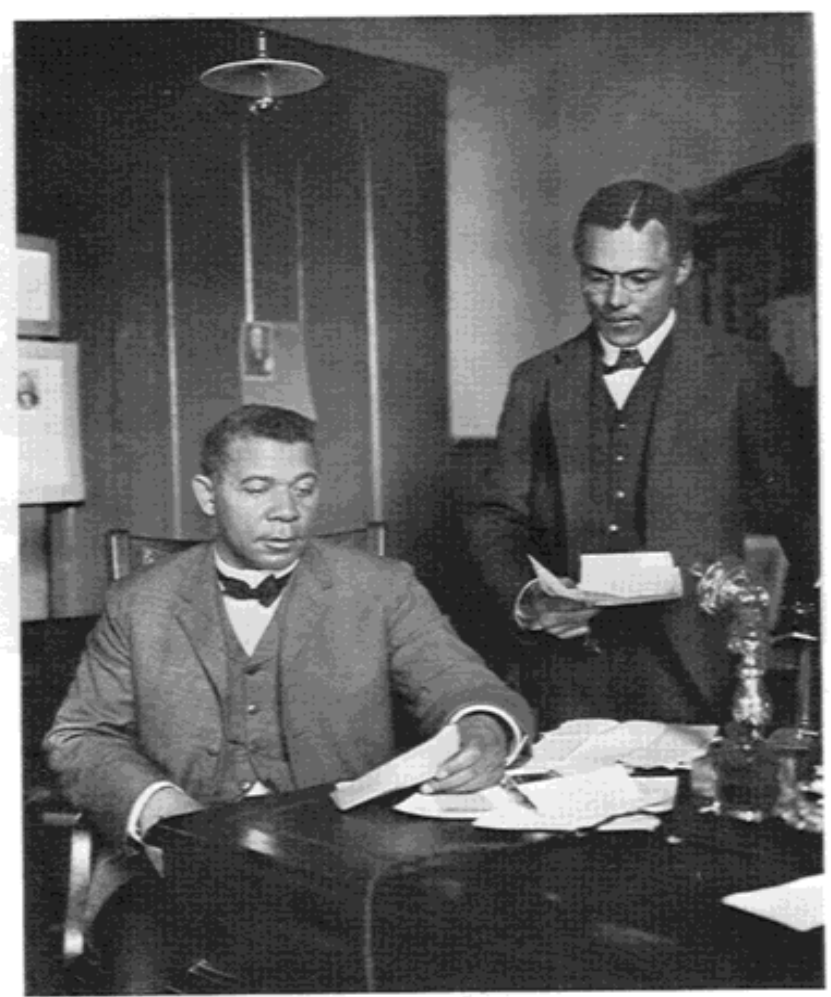

Booker T. Washington and Emmett J. Scott.

Fig. 9. O reitor do Instituto Tuskegee com seu secretário particular. Observe que o telefone é o terceiro "personagem" da foto.

De acordo com Bieze, a intenção de Washington quando encomendou as imagens do instituto que fundou foi exibi-las na Feira Mundial da cidade de St. Louis, no estado norte-americano de Louisiana, em 1904, mas as fotografias do negro como "sujeito" foram rejeitadas. ${ }^{48}$ Segundo Bieze:

A Exposição de Charleston de 1903 teve uma exposição fotográfica. Entretanto, o apoio do Governo Federal para a fotografia negra diminuiu após a Exposição de Paris. A Feira Mundial de St. Louis de 1904 projetou e depois abandonou uma enorme exposição de fotografias de Tuskegee da autoria de Frances Benjamin Johnston, eliminando assim qualquer presença contemporânea do African American. Mesmo assim, as exposições regionais continuaram [....] Só depois de várias gerações, fotógrafos como Gordon Parks e Ernest Withers oficialmente romperiam a "linha de cor" na mídia branca e os brancos tomariam consciência da fotografia negra ${ }^{49}$.

48 A Exposição de St. Louis não deixou de expor o negro para "ser visto" no contexto de um zoológico humano, inclusive num plantation, "mostrando a vida do negro [tal como era] antes da Guerra da Secessão" (BIEZE, 2008, p. 99).

${ }^{49}$ BIEZE, 2008, p. 102. 
Seguindo o ritmo cíclico das relações raciais iniciado com a Abolição nos Estados Unidos em 1865, o negro norte-americano conquistava avanços seguidos por retrocessos, progredindo no ritmo de "dois passos para frente, um passo para trás".

\title{
Propaganda, auto-promoção e lavagem cerebral
}

Outra função das imagens, ainda no século XIX, era a propaganda (inclusive a autopromoção). ${ }^{50}$ Um dos pioneiros nesta área nos Estados Unidos foi P.T. Barnum, fundador do famoso circo-espetáculo "Ringling Brothers \& Barnum \& Bailey". Segundo a biografia divulgada pelo site do próprio circo:

\begin{abstract}
No decorrer de seus 80 anos de vida, Barnum ofereceu ao "sábio público" do século XIX toda a gama, de artimanhas desavergonhadas a espetáculos inigualáveis entretenimento suficiente para ganha-lo o título de "mestre showman" uma dúzia de vezes. Quando escolheu Barnum como uma das 100 personagens mais importantes do milênio, a revista Life o apelidou 'o santo padroeiro dos marketeiros'51.
\end{abstract}

Outros figuras do Oitocentos que tornaram-se referências em relação a confecção de uma "identidade midiática moderna" foram o autor norte-americano Mark Twain e a atriz francesa Sarah Bernhardt. Bieze observa que, neste sentido, Washington se assemelha mais a esses personagens do que às figuras com as quais ele geralmente é comparado - ou seja, Frederick Douglass e W.E.B. Du Bois ${ }^{52}$.

Segundo Burke, "Uma solução mais comum para o problema de tornar concreto o abstrato é mostrar indivíduos como encarnações de idéias ou valores" ${ }^{\prime 3}$. Washington entendia esse conceito muito bem e procurou divulgar imagens dele mesmo e de seus colegas e colaboradores, que transmitiam os valores mais caros aos vitorianos brancos nos Estados Unidos - negros inteligentes, cultos e sofisticados e, para os supremacistas brancos do Sul, acima de tudo, negros que "conheciam seu lugar" e não apresentavam uma ameaça ao sistema de segregação chamado "Jim Crow" que substituiu a escravocracia. Nas suas próprias fotos, Washington pode ser visto montando cavalo, com a mão dentro do paletó, no estilo

\footnotetext{
${ }^{50} \mathrm{O}$ uso das imagens na publicidade pode ser verificado no Japão, em anúncios de saquê utilizando gravuras de Utamaro (1753-1806) (BURKE, Peter. Testemunba ocular, História e imagem. Bauru, SP: Edusc, 2004, p. 115).

51 RINGLING BROTHERS \& BARNUM \& BAILEY. "P.T. Barnum". Disponível em: $<$ http:/ / www.ringling.com/FlashSubContent.aspx?id=11734\&parentID=366\&assetFolderI=368>. Acessado em 31.12.10.

52 BIEZE. Booker T. Washington and the Art of Self-Representation, 2008, p. 112-113.

${ }^{53}$ BURKE, Peter. Testemunha ocular, História e imagem. Bauru, SP: Edusc, 2004, p. 81.
} 
napoleônico, e sentado em frente a mesas de trabalho ${ }^{54}$ - em um caso, equipada com um telefone (Fig. 9), uma tecnologia de ponta no início do século XX. ${ }^{55}$

Como vimos, Washington dirigia os seus livros e suas imagens a dois públicos - os brancos e os negros. Para ambos, era imprescindível combater e superar as imagens negativas do negro - estereótipos de inferioridade "de corpo e mente", ${ }^{66}$ luxúria, preguiça etc. disseminadas em jornais, revistas, postais e livros. Por exemplo, na edição de 1885 do livro Huckleberry Finn, de Mark Twain, onde Jim, o escravo foragido, é uma figura heróica, as pranchas mostram-no como uma figura infantil, quase animalesca (ver Fig. 10) ${ }^{57}$. Segundo o publicitário negro norte-americano Tom Burrell, desde o início do século XVII, quando os primeiros africanos desembarcaram nos futuros Estados Unidos, uma "campanha de propaganda" e lavagem cerebral vem reforçando os estereótipos da inferioridade negra e a superioridade branca, com resultados nefastos para o auto-estima do negro. ${ }^{58}$ Existem incontáveis exemplos de imagens derrogatórias que circulavam nos Estados Unidos, na Europa e no Brasil antes, depois e durante a virada do século XIX. O livro Eu tenho um sonho: De King a Obama - A saga negra do norte apresenta uma amostra destas imagens que ilustra a verdadeira feição do "dragão" imagético que Washington, Querino e outros líderes e intelectuais negros enfrentavam para combater os preconceitos dos brancos e servir como referências positivas para os seus irmãos de cor. ${ }^{59}$

\footnotetext{
${ }^{54}$ Uma pose que também pode ser chamada de napoleônica, uma vez que Burke observa que "o quadro de Napoleão em seu escritório, pintado por Jacques-Louis David (1748-1825), apresentou um aspecto relativamente novo do poder, o governante como burocrata[...]" (BURKE 2008, p. 86).

55 Ver nota no. 2.

${ }^{56}$ Nas palavras de Thomas Jefferson, o principal autor da Declaração da Independência dos Estados Unidos: "I advance it therefore as a suspicion only, that the blacks, whether originally a distinct race, or made distinct by time and circumstances, are inferior to the whites in the endowments both of body and mind" (1784).

57 TWAIN, Mark. Huckleberry Finn. Nova York: Charles Webster and Co., 1885. Disponível em: <http://www.gutenberg.org/files/76/76-h/76-h.htm> Acesso em 09.01.2011.

58 BURRELL, Tom. Brainwashed: Challenging the Myth of Black Inferiority. Carlsbad, Califórnia: SmileyBooks, 2010.

59 ARAÚJO, Emanuel (Org.). Eu tenho um sonho: De King a Obama - A saga negra do norte. São Paulo: Museuafrobrasil, 2011.
} 


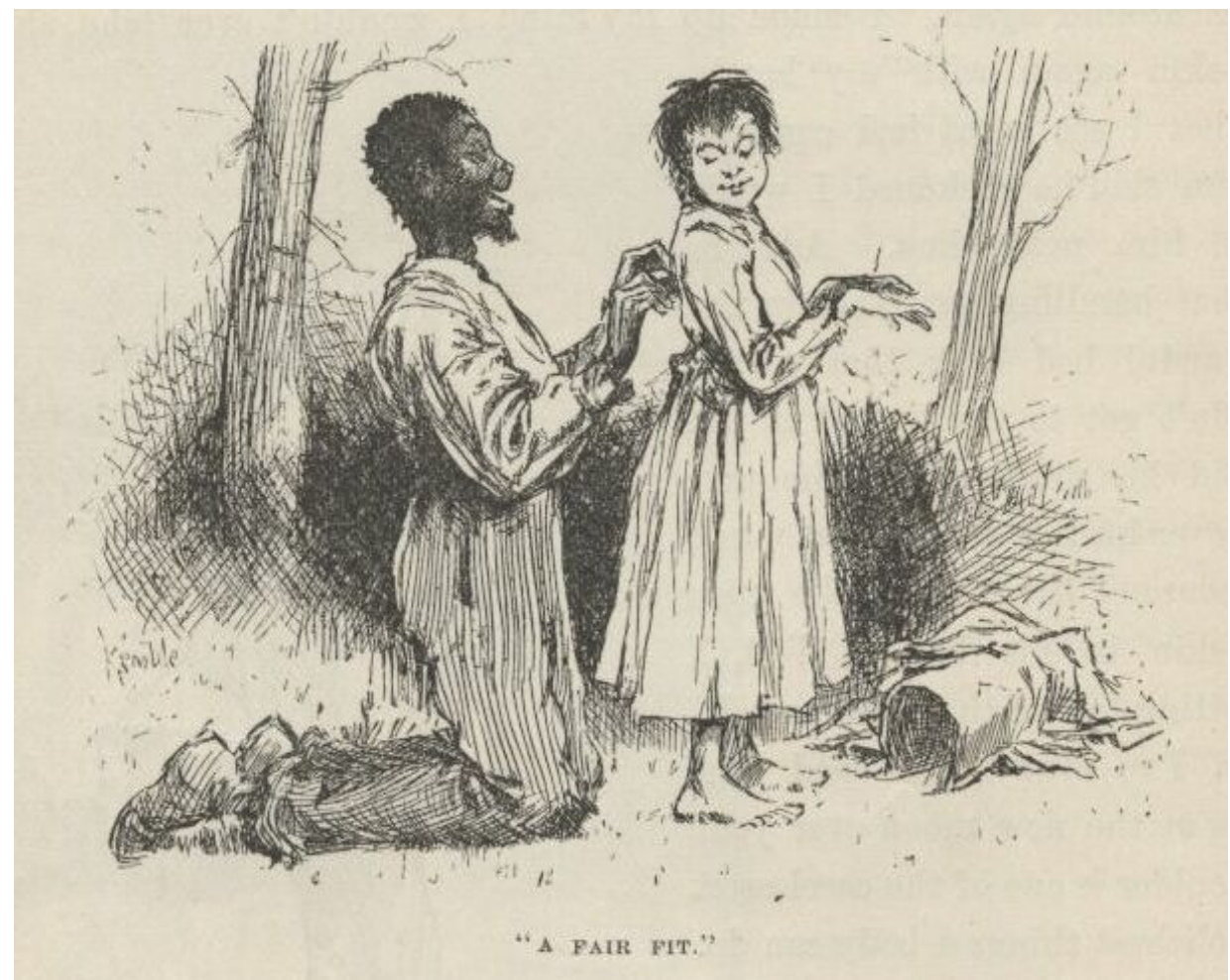

Fig 10. Ilustração de Huckleberry Finn (1885). Nesta imagem, o perfil de Jim se assemelha mais ao focinho de um cão do que ao rosto um ser humano.

\section{As pranchas de $\boldsymbol{A}$ raça africana}

Querino usou fotografias para combater as imagens negativas e cientificistas do negro de duas maneiras: primeiro, divulgando sua própria imagem de um "homem de cor" altivo e sofisticado e segundo, divulgando imagens respeitosas e dignas de africanos e afrodescendentes. Enfim, almejava a representação de tudo que era "civilizado" nos olhos dos brancos, contrariando o estereótipo de "corpos robustos, nus pela metade, [...] fisionomias desinteligentes" promulgado por Louis Agassiz e seus semelhantes. ${ }^{60}$

O livro A raça africana (1955) é ilustrado por 25 pranchas - 23 fotografias e 2 gravuras (entre elas, Figs. 11 a 14 e 16 a 24). Nove das fotografias retratam "typos" e "representantes" de "tribos" africanas, representando pessoas anônimas ${ }^{61}$ ou identificadas apenas pelo cargo, no caso da "antiga mãe de terreiro do Gantois, Typo Egbá" (Fig. 22, estampa XII-a); cinco são fotografias privadas de indivíduos e grupos de pessoas. Também incluem uma fotografia

\footnotetext{
60 AGASSIZ, Louis \& Agassiz, Elizabeth Cary. Viagem ao Brasil - 1865-1866. Tradução e notas de Edgar Süssekind de Mendonça. Brasília: Senado Federal, 2000, p. 66.

${ }^{61}$ Em alguns casos, é possível identificar a pessoa retratada, como a "Typo Igê-chá", que foi identificada como Manjegbassa, a mãe de Martiniano Eliseu do Bonfim.
} 
intitulada "Ganhadores de Canto", uma imagem amplamente disseminada em que todos estão descalços, indicando sua condição de escravos, mas dignamente trajados com paletós escuros e chapéus (estampa XVIII, Fig. 24). A extrema direita da foto, vemos Felisberto Couve, um exrei africano e sacerdote de Ifá. Também se vê sombrinhas - símbolos de realeza em várias regiões da África - uma das quais está encostada contra a parede. ${ }^{62}$

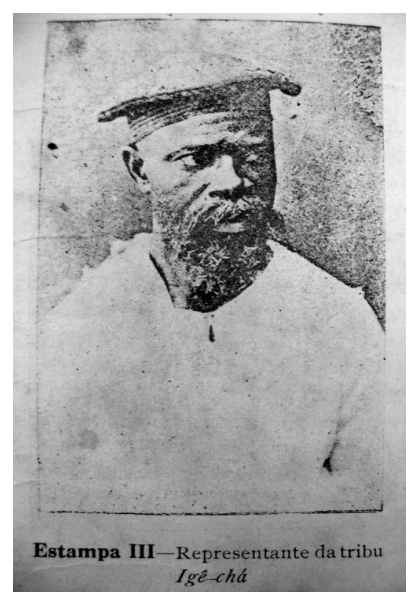

Fig.11 Estampa III Representante da Tribu Igê-chá

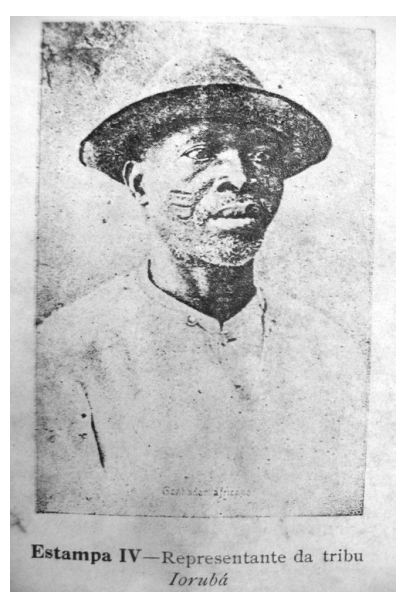

Fig. 12 Estampa IV Representante da Tribu Iorubá

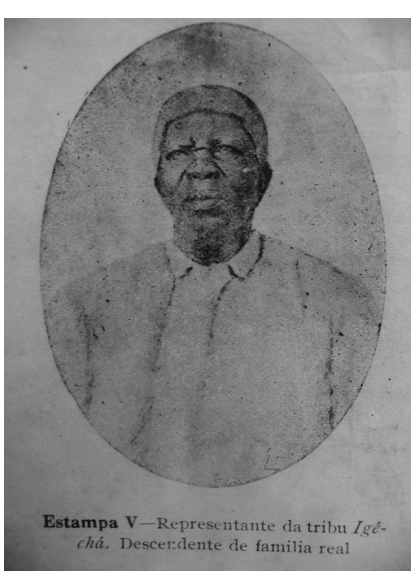

Fig. 13. Estampa V Representante da Tribu Igê-chá.

Descendente de família real

\footnotetext{
${ }^{62}$ Outras imagens mostram escravos e libertos com sombrinhas, mas não necessariamente como símbolos de realeza - possivelmente representando apenas as mercadorias que vendiam. Ver AZEVEDO, Paulo Cesar de, e LISSOVSKY, Mauricio (Orgs.). Escravos brasileiros do século XIX na fotografia de Christiano Jr. São Paulo: Ex Libris, 1988.
} 


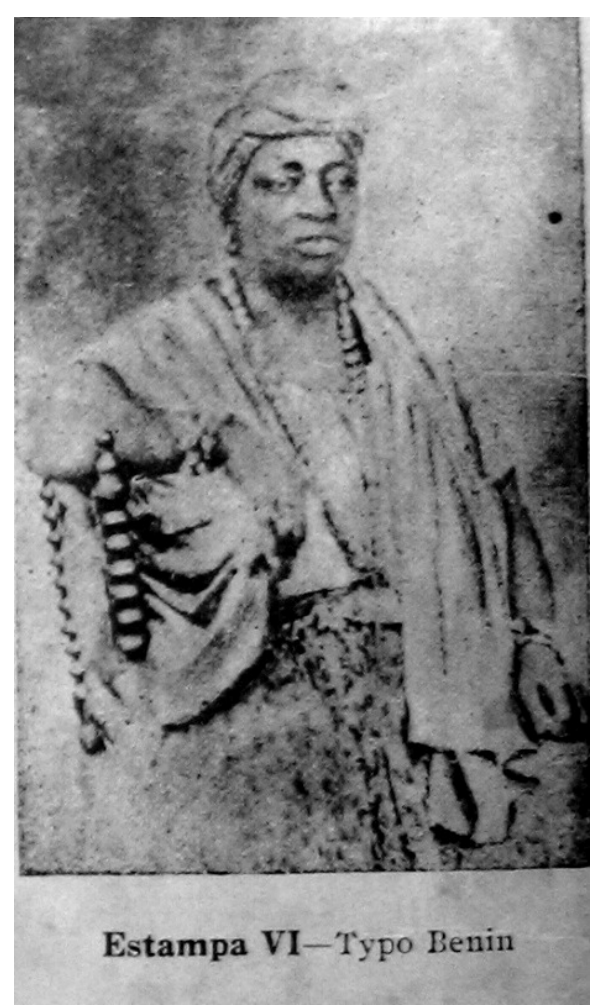

Fig. 14 Typo Benin

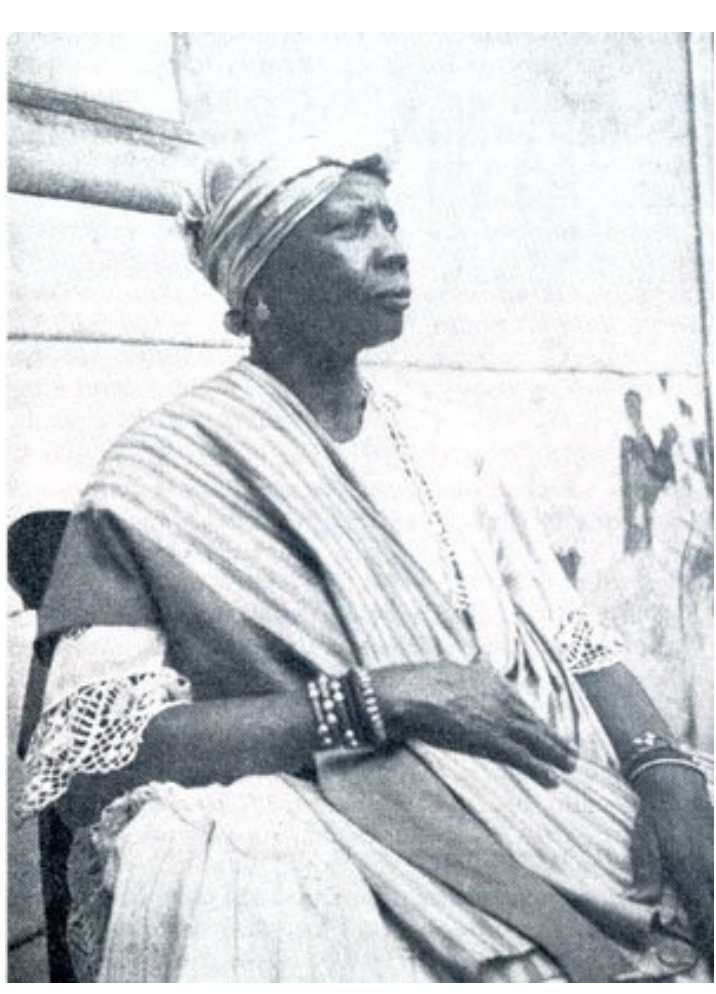

Fig. 15a Mãe Aninha, fundadora do Opo Afonjá Fonte: Wikipedia

Quase todas as mulheres que aparecem nestas fotografias usam um pano da costa no ombro, no estilo não-litúrgico - durante rituais de Candomblé, seria usado em torno da cintura pelas mais velhas e em torno do peito pelas mais novas. Este modo de vestir foi descrito pelo autor francês C.M.A. Dugrivel no início da década de 1830: “Todas as negras em geral se vestem com um pano da costa, espécie de manto à grega, com que elas se cobrem com uma graça divina. Como eu gosto de tudo que é antigo, você deve imaginar como me dá prazer observar estes costumes que relembram os belos tempos de Temístocles, de Péricles" ${ }^{\text {"3. }}$.

A posição e a maneira de usar o pano da costa da mulher que representa o "Typo Benin" na "Estampa VI” (Fig. 14), provavelmente retratada no início do século XX, são muito parecidas com alguns retratos das ialorixás do Ilê Axé Opô Afonjá - Mãe Stella de Oxossi dá continuidade a essa tradição numa fotografia da autoria de Mário Cravo Neto, produzida no final do século, no ano 1999 (Figs. 15a e 15b). Segundo Christiane Vasconcellos:

\footnotetext{
${ }^{63}$ DUGRIVEL, C.M.A. Des bordes de la Saône à la baie de San Salvador ou promenade sentimentale en France et au Brésil. Paris: Lacour, 1843.Querino teria gostado desta comparação com a Grécia Antiga, uma vez que fez questão de comparar os escravos africanos no Brasil com os escravos gregos de Roma.
} 
$\mathrm{Na}$ coleção formada por Querino as fotografias que tematizaram o candomblé, foram realizadas pela Photografia Diamantina, estabelecida na Rua Dr Seabra, Baixa do Sapateiro, área de comércio popular, cuja localização afastava-se do circuito comercial dos outros ateliês existentes na cidade, situados nas freguesias da Sé e São Pedro.[...] É interessante notar que as fotografias de mães-de-santo, que surgiram apenas nas primeiras décadas do século XX, foram produzidas pela Photographia Diamantina. A importância do ateliê está na evidência da auto-representação dessa parcela da população negra que almejou e pagou pelo seu retrato; simultâneo à produção e circulação de fotografias públicas da gente negra escolhida pelos fotógrafos europeus para compor as séries de tipos urbanos da Bahia ${ }^{64}$.

Duas dessas fotografias (Figs. 22 e 23) seguem o estilo de cartes-cabinet - a da "antiga mãe de terreiro", facilmente identificada como Maria Júlia da Conceição Nazareth, a fundadora do Ilê Iyá Omin Axé Iyá Massé, ou terreiro do Gantois, e a de sua filha biológica e sucessora, Maria Pulquéria da Conceição Nazareth (1840-1918), “carismática e respeitada ialorixá que

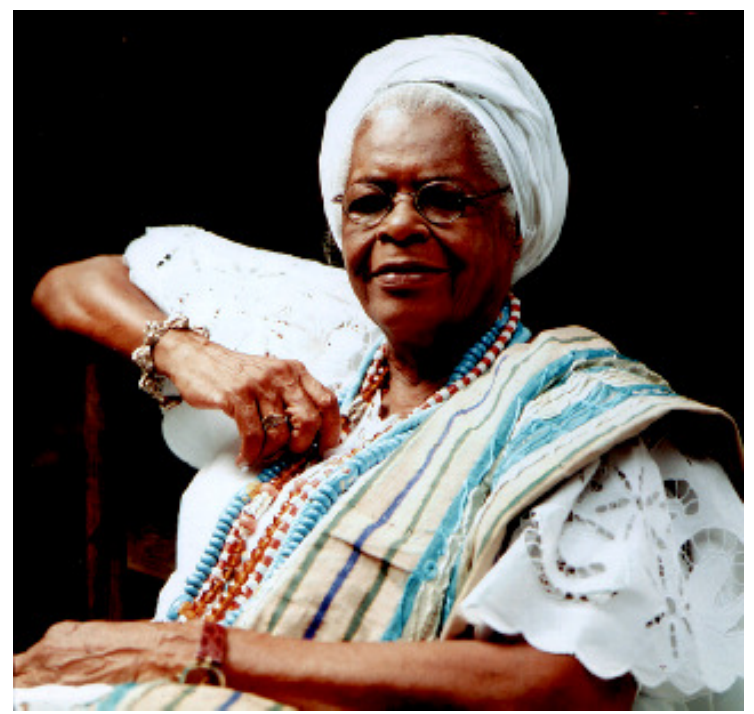

Fig. 15b Mãe Stella. Foto: Mario Cravo Neto abriu as portas do terreiro para pesquisas aos intelectuais" ${ }^{\prime 65}$. A segunda também era mãe de santo de Querino, quando foi ogã do Gantois $^{66}$. As duas mulheres são retratadas de pé, de corpo inteiro, trajando roupas e jóias que, no segundo retrato, Querino caracteriza como sendo de "grande gala". Tanto a mãe como a filha tem porte de rainha.

Os símbolos de realeza e as poses aristocráticas podem ser interpretações subjetivas em algumas dessas imagens, mas outra fotografia não deixa dúvidas - segundo Querino, representa um descendente de família real ijexá (Fig. 13, Estampa V). Na apresentação de “A raça africana", o pesquisador lamenta que "se extinguiram, precisamente, os africanos que, sendo aqui escravizados, ocuparam, na terra natal, posição social elevada, como guia dos destinos da

\footnotetext{
${ }^{64}$ VASCONCELLOS, Christiane. "O Uso de Fotografias de Africanos no Estudo Etnográfico de Manuel Querino”, In Sankofa. Revista de História da África e de Estudos da Diáspora Africana, no. 4 dez. 2009, p. 88-111.

${ }^{65}$ NOBREGA, Cida e ECHEVARRIA, Regina. Mãe Menininha do Gantois. Salvador: Editora Corrupio, 2006, p. 16 e 17.

${ }^{66}$ LIMA, Vivaldo da Costa. Sobre Manuel Querino, in A anatomia do acarajé e outros escritos. Salvador: Corrupio, 2010, p. 87-97. P. 94.
} 
tribo, on como depositários dos segredos da seita religiosa ${ }^{967}$. Em meados do século XIX, o cônsul inglês James Wetherell comentou, com um tom de deboche bem britânico, sobre a existência de “príncipes pretos" em Salvador:

Existem alguns pretos que eram príncipes em seu pais e, cada vez que se encontram com um dos seus conterrâneos, este nunca deixa de ajoelhar-se para cumprimentálos. Falam quase sempre muito alto e, quando é possível, mantêm a conversação em sua própria língua. Ao encontrarem-se, têm quase sempre algo para dizer e, no decorrer da conversa, após fazer uma pergunta, parecem repetir numerosas vezes a mesma palavra ou palavras. Freqüentemente falam em alta voz para si mesmo, e, em quase todos os casos, o assunto de seu solilóquio é o dinheiro. ${ }^{68}$

Segundo Alberto da Costa e Silva, a presença de pessoas de "posição social elevada" entre os africanos escravizados no Brasil, e descendentes da realeza africana é hoje mais que comprovada. ${ }^{69}$

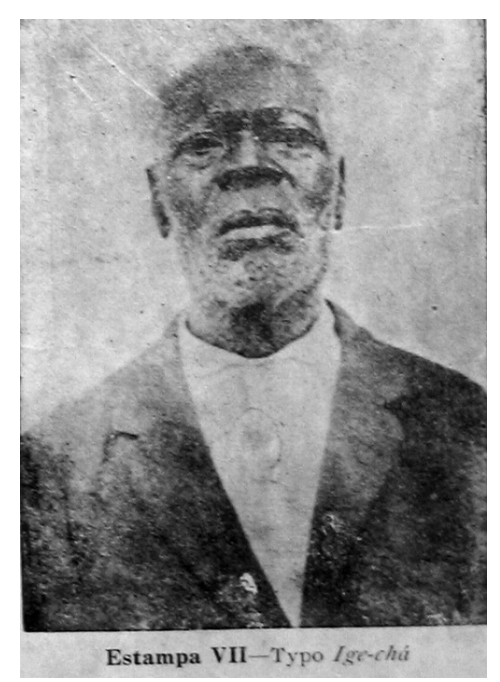

Fig. 16 Estampa VII Typo Igê Chá

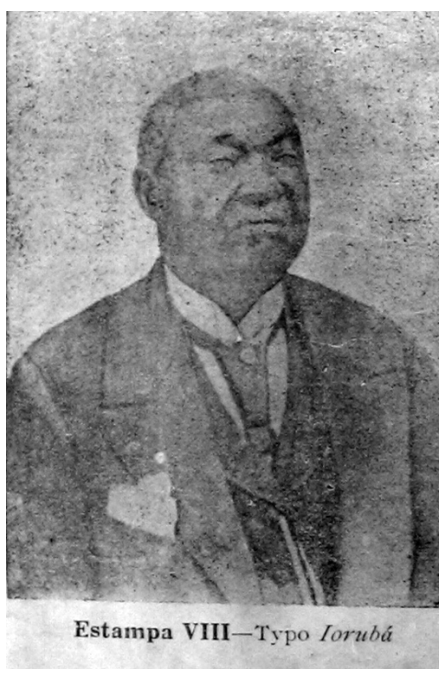

Fig. 17 Estampa VIII Typo Iorubá

${ }^{67}$ QUERINO, Manuel. A raça africana e seus costumes na Babia. Salvador: P555 Edições/Theatro XVIII, 2006, p. 1112 (grifo nosso).

68 WETHERELL, James. Brasil, Apontamentos sobre a Babia. Salvador, Edição Banco da Bahia S/A, p. 18.

${ }^{69}$ COSTA E SILVA, Alberto da. "Portraits of African Royalty in Brazil," In Lovejoy, Paul E.(ed.), Identity in the Shadow of Slavery Londres: Continuum, 2000, p. 129-136. 


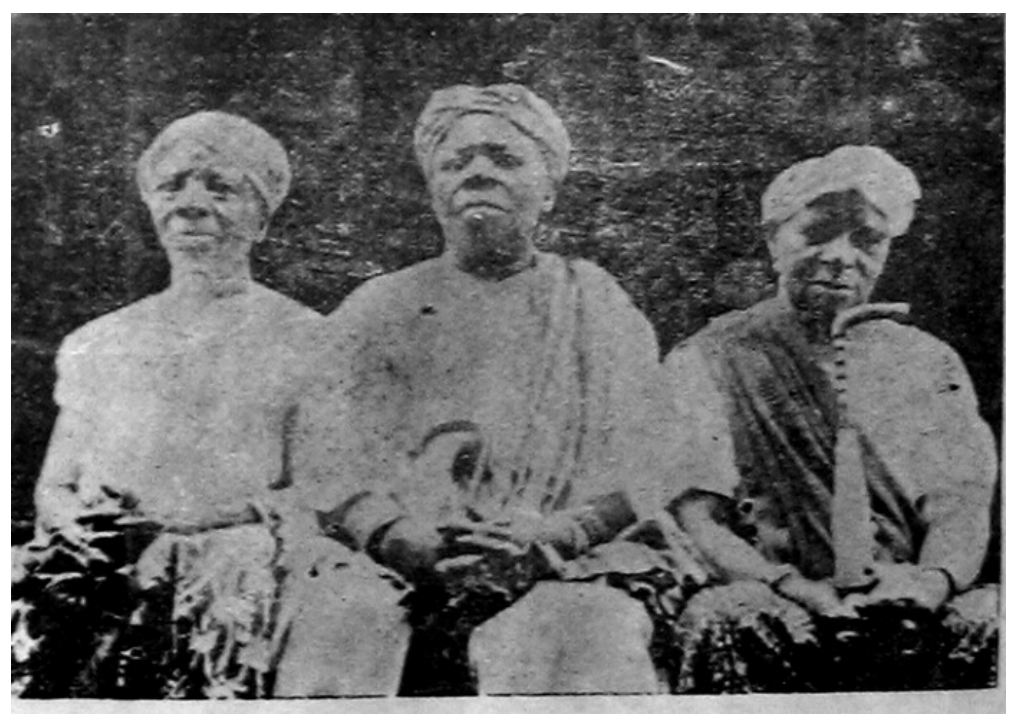

Fig. 18. Estampa IX Oondó, Igê-chá, Igechá

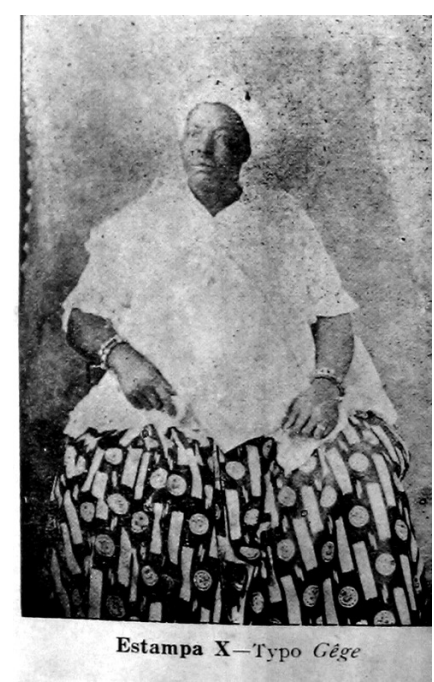

Fig. 19. Estampa X. Typo Gêge da Tribu Ige-chá

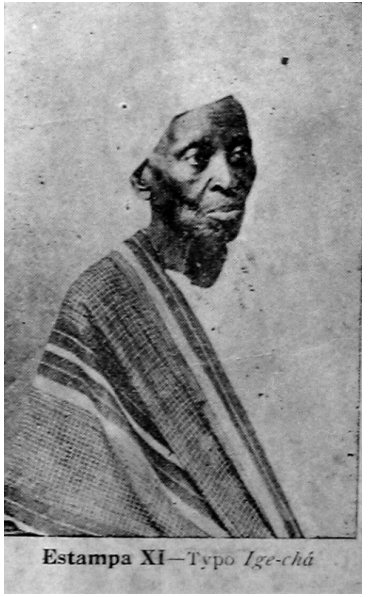

Fig 20. Estampa XI Typo Igê-chá

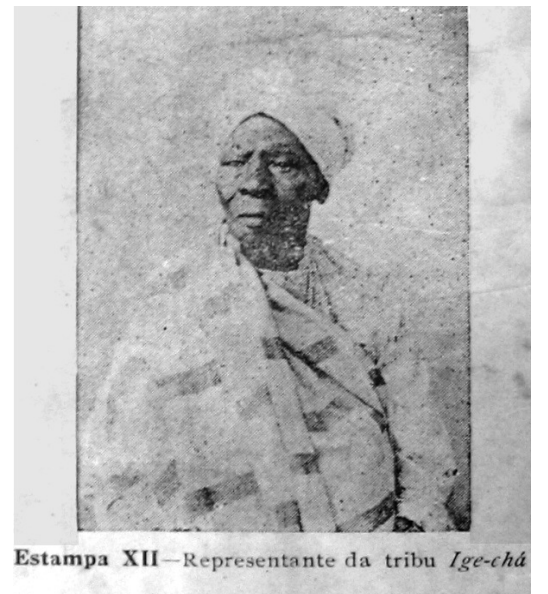

Fig 21 Estampa XII Representante 


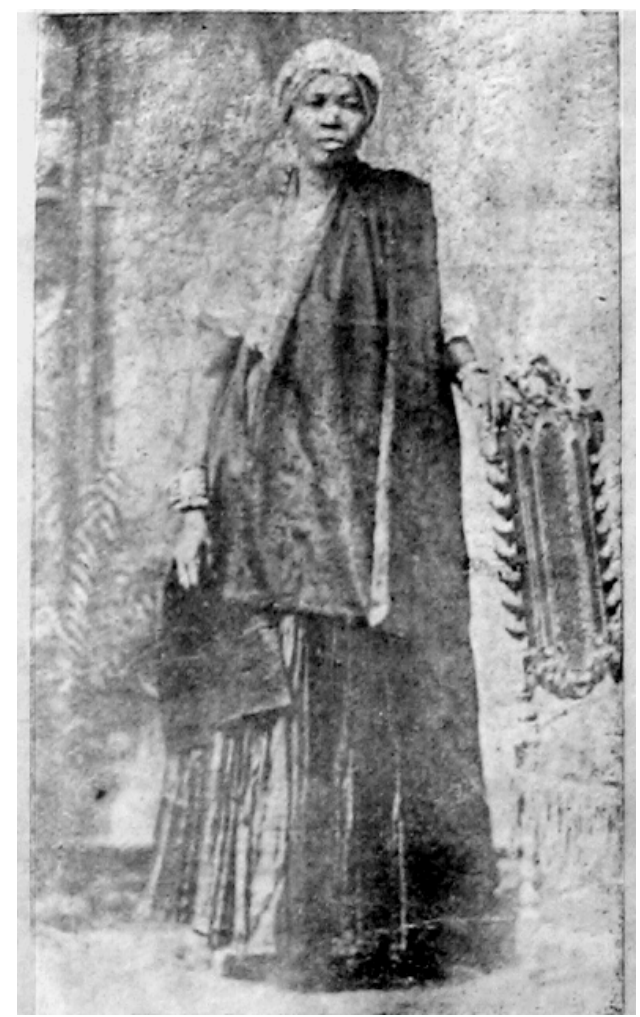

Fig 22. Estampa XII-a A antiga mãe de terreiro do Gantois. Typo Egbá

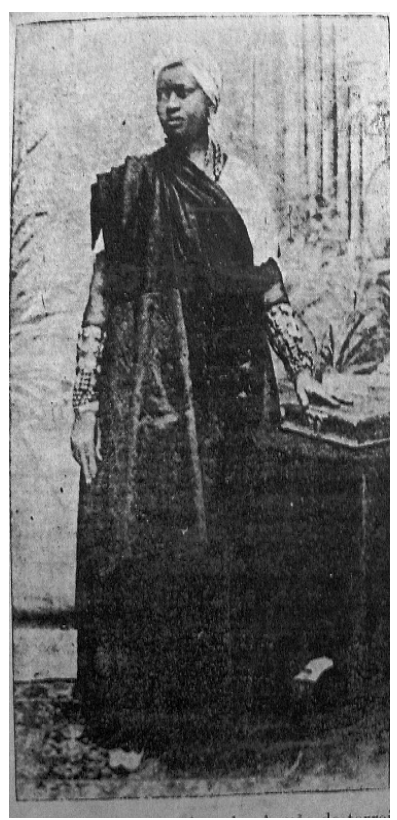

Fig 23. Estampa XXIII. Creoula em grande gala. A mãe de terreiro do Gantois. Pulchéria Maria da Conceição 


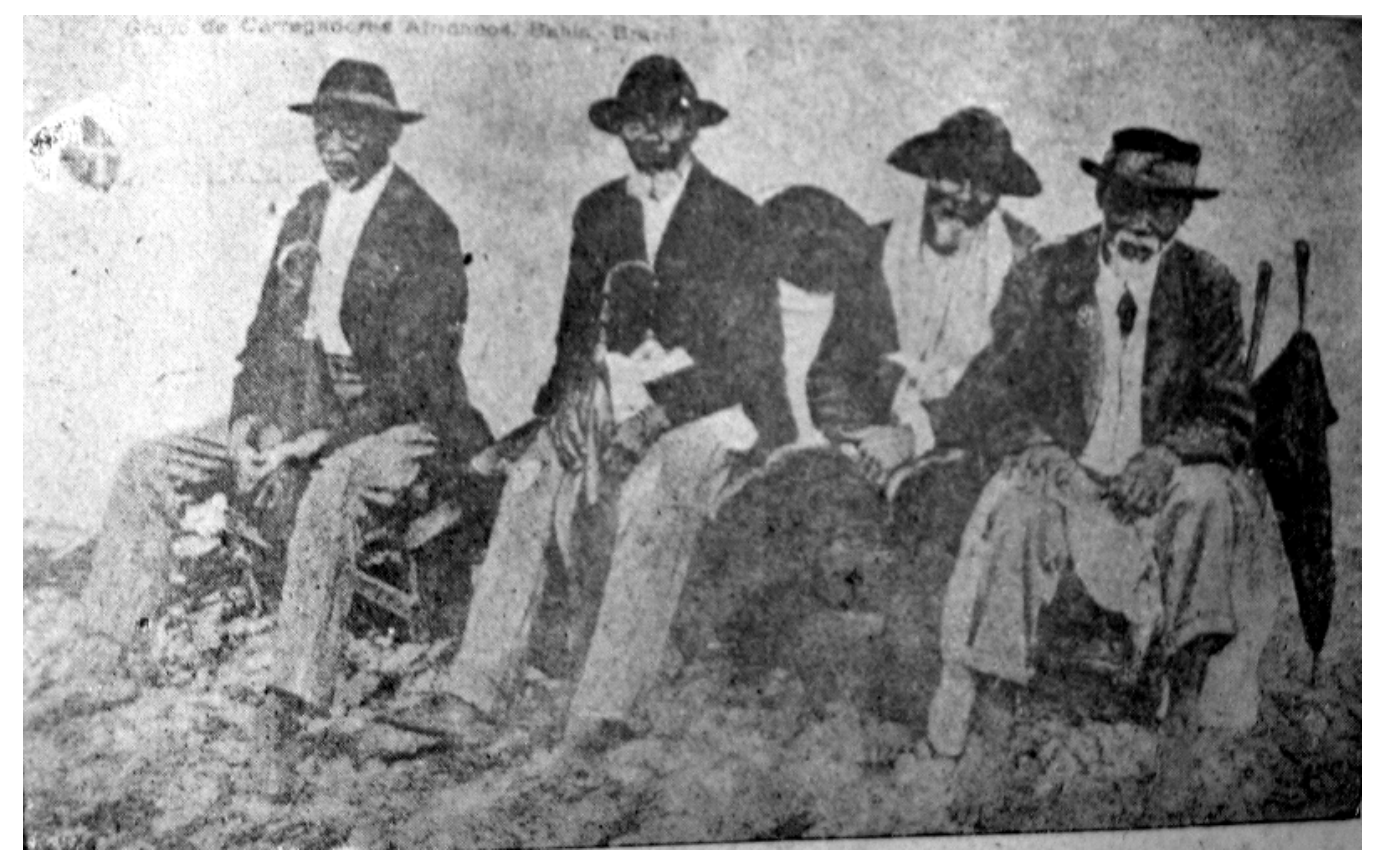

Fig 24 Estampa XVIII Ganhadores no Canto

O uso que Manuel Querino fez de imagens de africanos e "crioulos" que contrariavam a iconografia humilhante produzida pelos cientificistas veio complementar seus trabalhos escritos, que sempre realçavam as contribuições positivas do "colono preto". Devido à vergonha latente quanto à ancestralidade mestiça do Brasil, gerada e mantida pelo racismo científico, escassa atenção foi prestada por historiadores brasileiros à contribuição do africano e seus descendentes à civilização brasileira até a terceira década do século XX. A imagem predominante do negro era a de um instrumento passivo do trabalho, um bem possuído pelo senhor de escravos e seu papel no movimento abolicionista passava despercebido. Numa tentativa de branquear a imagem do Brasil e sua historiografia, o negro foi relegado a algumas poucas páginas referentes à escravidão e à Lei Áurea. Decidido a reverter essa tendência, Querino também destacou as contribuições mais recentes do negro e seus descendentes em várias obras. Em "O colono preto como fator da civilização", por exemplo, fornece a seguinte relação de nomes ilustres:

Sem nenhum esforço, pudemos aqui citar o Visconde de Jequitinhonha, Caetano Lopes de Moura, Eunápio Deiró, a privilegiada família dos Rebouças, Gonçalves Dias, Machado de Assis, Cruz e Souza, José Agostinho, Visconde de Inhomirim, Saldanha Marinho, Padre José Maurício, Tobias Barreto, Lino Coutinho, Francisco Glicério, Natividade Saldanha, José do Patrocínio, José Teófilo de Jesus, Damião 
Barbosa, Chagas, o Cabra, João da Veiga Muricí e muitos outros, só para falar dos mortos $^{70}$.

Em 1923, a Revista do Instituto Geográfico e Histórico da Babia (no. 48, 353-363) publicou um artigo da autoria de Professor Manuel Querino, titulado "Os homens de côr preta na Historia", no qual o autor fornece dados biográficos (em muitos casos, escassos, com apenas 3 linhas) de 38 ilustres afrodescendentes: médicos, militares, religiosos, revolucionários, bacharéis, músicos e educadores, além de um engenheiro (Emigdio Augusto de Mattos). Também cita os nomes de vários outros militares (tenentes e alferes) e educadores. Embora a maioria não tenha data, quase todos são do século XIX. Neste esforço, Querino seguia o exemplo da imprensa negra que, no século XIX, procurou apresentar personagens ilustres "de cor" para fornecer referências positivas para o negro e combater os estereótipos que o cercavam e ainda o cercam no Brasil. ${ }^{71}$ Podemos acrescentar a seus esforços literários o uso de imagens para enfrentar o cientificismo.

\section{Bibliografia:}

1. AGASSIZ, Louis \& Agassiz, Elizabeth Cary. Viagem ao Brasil - 1865-1866. Tradução e notas de Edgar Süssekind de Mendonça. Brasília: Senado Federal, 2000.

2. ARAÚJO, Emanuel (Org.). Eu tenho um sonbo: De King a Obama - A saga negra do norte. São Paulo: Museuafrobrasil, 2011.

3. AZEVEDO, Paulo Cesar de, e LISSOVSKY, Mauricio (Orgs.). Escravos brasileiros do século XIX na fotografia de Christiano Jr. São Paulo: Ex Libris, 1988.

4. BARTHES, Roland. A camara clara. Rio de Janeiro: Nova Fronteira, 1984.

5. BECKER, William B. "Cabinet Cards", In HANNAVY, John (ed.), Encyclopedia of Nineteenth-Century Photography, vol. 1, p. 233-234. Nova York: Routledge, 2008. P. 233234.

6. BIEZE, Michael. Booker T. Washington and the Art of Self-Representation. Nova York: Peter Lang, 2008.

7. BLANCHARD, Pascal et alii (eds.) Human Zoos : Science and Spectacle in the Age of Colonial Empires, traduzido por Teresa Bridgeman. Liverpool: Liverpool University Press, 2008.

8. BURKE, Peter. Testemunha ocular, História e imagem. Bauru, SP: Edusc, 2004.

\footnotetext{
${ }^{70}$ QUERINO, Manuel. Costumes africanos no Brasil. Prefácio e notas de Artur Ramos. Rio de Janeiro: Civilização Brasileira, 1938, p. 160, grifo nosso.

${ }^{71}$ PINTO, Ana Flávia Magalhães. De pele escura e tinta preta: A imprensa negra do século XIX (1833-1899). Dissertação (Mestrado em História) - Universidade de Brasília, Brasília, 2006, p. 98. O semanário pernambucano O Homem: Realidade Constitucional ou Dissolução Social foi lançado no Recife em 13 de janeiro de 1876 e a edição do mês de março do mesmo ano, continha uma seção entitulada "Galeria de Homens de Cor Ilustres", a qual era "dirigida majoritariamente à valorização de personagens negros da história brasileira, o que se inscreve no trabalho de fortalecimento dessa população" (PINTO 2006, p. 124.)
} 
9. BURRELL, Tom. Brainwashed: Challenging the Myth of Black Inferiority. Carlsbad, Califórnia: SmileyBooks, 2010.

10. CUNHA, Manuela Carneiro da. "Olhar Escravo, Ser Olhado", In AZEVEDO, Paulo Cesar de, e LISSOVSKY, Mauricio (Orgs.). Escravos brasileiros do século XIX na fotografia de Christiano Jr. São Paulo: Ex Libris, 1988.

11. COSTA E SILVA, Alberto da. "Portraits of African Royalty in Brazil," In Lovejoy, Paul E.(ed.), Identity in the Shadow of Slavery Londres: Continuum, 2000.

12. COUVE, Antenor Boaventura. Narrativa de um Descendente de um rei africano escravo na Bahia, publicada na revista Almanaque Do Mensageiro da Fé, Ano 1964. pág. 96/99 - Salvador/BA. Disponível em: <http://bahiatextos.blogspot.com/2010/05/meu-avo-rei-ossurumis.html> Acesso em: 13.01.11.

13. DU BOIS, W.E.B. The Souls of Black Folk. Nova York: Barnes \& Noble, 2003.

14. DUGRIVEL, C.M.A. Des bordes de la Saône à la baie de San Salvador ou promenade sentimentale en France et au Brésil. Paris: Lacour, 1843.

15. ERMAKOFF, George. O negro na fotografia brasileira do século XIX. Rio de Janeiro: George Ermakoff Casa Editorial, 2004.

16. GOULD, Stephen Jay. A falsa medida do homem. São Paulo: Martins Fontes, 2003.

17. KING, Reyahn et alii. Ignatius Sancho: An African Man of Letters. Londres: National Portrait Gallery, 1997.

18. LIMA, Vivaldo da Costa. Sobre Manuel Querino, in A anatomia do acarajé e outros escritos. Salvador: Corrupio, 2010.

19. MACHADO, Maria Helena, e HUBER, Sasha. (T)races of Louis Agassiz: Photography, Body and Science, Yesterday and Today/Rastros e Raças de Louis Agassiz: Fotografia, Corpo e Ciência, Ontem e Hoje. Publicado na ocasião da $29^{a}$ Bienal de São Paulo. São Paulo: Capacete Entretenimentos, 2010.

20. MAXELL, Anne. "Montrer l'Autre: Franz Boas et les soeurs Gerhard", In BANCEL, Nicolas, et alii, Zoos humains. De la Vénus hottentote aux reality shows. Paris: La Découverte, 2002.

21. MIRZOEFF, Nicholas. Bodyscape: Art, modernity and the ideal figure. Londres e Nova York: Routledge, 1995.

22. NOBREGA, Cida e ECHEVARRIA, Regina. Mãe Menininha do Gantois. Salvador: Editora Corrupio, 2006.

23. QUERINO, Manuel. "Os homens de côr preta na Historia." Revista do Instituto Geográfico e Histórico da Bahia, Salvador, 48, 353-363, 1923.

24. RINGLING BROTHERS \& BARNUM \& BAILEY. "P.T. Barnum". Disponível em: $<$ http://www.ringling.com/FlashSubContent.aspx?id=11734\&parentID=366\&assetF olderI $=368>$. Acessado em 31.12.10.

25. RODRIGUES, Raimundo Nina. As raças bumanas e a responsabilidade penal no Brazil. Bahia: Imprensa Popular, 1894.

26. SAMPAIO, Moiseis de Oliveira. O coronel negro: Coronelismo e poder no norte da Chapada Diamantina. Dissertação (Mestrado em História Regional e Local), UNEB, Salvador, 2009.

27. SMITH, Shawn Michelle. "Photographing the 'American Negro': Nation, Race and Photography at the Paris Exposition of 1900", In BLOOM, Lisa (ed.), With Other Eyes: Looking at Race and Gender in Visual Culture. Minneapolis e Londres: University of Minnesota Press, 1999, p. 58-87. 
28. TRACHTENBERG, Alan. Reading American Photographs: Images as History, Mathew Brady to Walker Evans. Nova York: Hill and Wang, 1990.

29. TURAZZI, Maria Inez. Poses e trejeitos, a fotografia e as exposições na era do espetáculo (18391889). Rio de Janeiro: Funarte/Rocco, 1995.

30. TWAIN, Mark. Huckleberry Finn. Nova York: Charles Webster and Co., 1885. Disponível em: <http://www.gutenberg.org/files/76/76-h/76-h.htm> Acesso em 09.01.2011.

31. VASCONCELLOS, Christiane. "O Uso de Fotografias de Africanos no Estudo Etnográfico de Manuel Querino", In Sankofa. Revista de História da Africa e de Estudos da Diáspora Africana, no. 4 dez. 2009, p. 88-111.

32. WALLIS, Brian. "Black Bodies, White Science: Louis Agassiz's Slave Daguerreotypes", In American Art, vol. 9, no. 2 (Summer 1995), p. 39-61.

33. WETHERELL, James. Brasil, Apontamentos sobre a Babia. Salvador, Edição Banco da Bahia S/A.

34. WESTERBECK, Colin L. "Frederick Douglass Chooses His Moment". Museum Studies. The Art Institute of Chicago, 2000. Disponível em <http://www.artic.edu/webspaces/museumstudies/ms242/westerbeck1.shtml> Acessado em 28 de Agosto 2009, p. 147.

Artigo recebido em: 22/04/2011

Aceito para publicação em: 20/06/2011 